\title{
Nonlinear Large Deformation Mechanism and Stability Control of Deep Soft Rock Roadway: A Case Study in China
}

\author{
Dong Wang ${ }^{1,2} \mathbb{D}$, Yujing Jiang ${ }^{1,3} \mathbb{D}$, Xiaoming Sun ${ }^{2, *}$, Hengjie Luan ${ }^{1}$ and Hui Zhang ${ }^{2}$ \\ 1 State Key Laboratory of Mining Disaster Prevention and Control Co-Founded by Shandong Province and the \\ Ministry of Science and Technology, Shandong University of Science and Technology, Qingdao 266590, \\ China; wdwinter@163.com (D.W.); jiang@nagasaki-u.ac.jp (Y.J.); luanjie0330@126.com (H.L.) \\ 2 State Key Laboratory for Geomechanics and Deep Underground Engineering, China University of Mining \\ and Technology, Beijing 100083, China; zhanghui123579@163.com \\ 3 School of Engineering, Nagasaki University, Nagasaki 852-8521, Japan \\ * Correspondence: sxmcumtb@163.com; +86-10-62331294
}

Received: 10 September 2019; Accepted: 1 November 2019; Published: 7 November 2019

\begin{abstract}
Improving the safety and stability of soft surrounding rock with nonlinear large deformation gives a strong guarantee for the safe mining and sustainable development of deep coal mines. In order to control the nonlinear large deformation of the surrounding rock in a deep soft rock roadway, this paper discusses the nonlinear large deformation mechanism and coupling support countermeasures of a typical engineering application at Xin'an coal mine in Gansu province, China. The series of experiments and theoretical analysis described in this paper reveal the phenomena, properties, and reasons for the nonlinear large deformation of soft surrounding rock in detail. Then, the type of nonlinear large deformation mechanism is determined and transformed from a composite one to a simple one. Based on experimental results and mechanism transformation, a suitable coupling support countermeasure, which contains the Constant Resistance Large Deformation (CRLD) bolt, steel mesh, floor hollow grouting cable, and steel fiber concrete, is proposed to reduce the nonlinear large deformation and the potential risk during mining. The application shows that the coupling support countermeasure can effectively reduce the nonlinear large deformation of the surrounding rock and help to maintain the stability of the deep soft rock roadway at Xin'an coal mine.
\end{abstract}

Keywords: deep; soft rock roadway; nonlinear large deformation; coupling support

\section{Introduction}

According to the latest BP statistical review of world energy, 2018 saw a further bounce back in coal, with both consumption and production increasing at their fastest rates for five years [1]. Coal's share in primary energy was $27.2 \%$ in 2018. Global coal production rose by 162 mtoe, especially in China (82 mtoe), providing the largest increments [1]. In China, the proportion of coal consumption in primary energy consumption was approximately $58.0 \%$ in 2018 , more than twice the proportion worldwide [1,2]. So, coal resources will occupy the priority position in primary energy consumption structure in the coming years. Ensuring the safe and sustainable production of coal resources is a key energy problem that people have to face.

With the increasing intensity of coal mining, the amount of shallow coal resources is decreasing day by day, forcing the gradual transformation of mining activities from shallow to deep [3]. Many coal mines have entered a deep mining phase [3,4]. With the increase in mining depth, the control of deep soft rock roadway has become the focus of researchers' attention. Under the complex engineering geological conditions, the surrounding rock produces significant plastic deformation, and various 
nonlinear mechanical phenomena become more and more intense in the deep soft rock roadways [4-6]. A series of nonlinear large deformation of surrounding rocks, such as roof sinking, shrinkage, floor heave, roof caving, rock burst, and ground burst have appeared in roadways [7-9]. The support mechanism and control countermeasure adopted in shallow mining have some limitations, which cannot fully adapt to deep mining activities. Therefore, revealing the nonlinear large deformation mechanism and proposing effective control countermeasures for deep soft rock roadways have been major scientific problems that have plagued the sustainable and safe production of coal mines.

Deep soft rock possesses the characteristics of large nonlinear deformation, which makes the deformation mechanism of deep soft rock roadways significantly different from that of shallow hard rock roadways [8]. The large deformation seriously affects the support effect of the support materials and brings considerable difficulty to the support of deep soft rock roadways [8-10]. Conventional support materials and support technology universally used in shallow hard rock roadways are unsuitable for deep soft rock roadways, which seriously affects the safety and stability of deep soft rock roadways [9-11].

As a support material, the traditional rock bolt mainly adopts the screw steel bolt, which has a small, mainly elastic deformation, which cannot cope with the large deformation of surrounding rocks. In order to remove the disadvantage of the small deformation of the traditional rigid bolt, many researchers have carried out a lot of work on support materials with long deformation. Typical tensile bolts are the D bolt, Cone bolt, Roofex bolt, and Constant Resistance Large Deformation bolt [12-18]. Especially, the Constant Resistance Large Deformation (CRLD) bolt, invented at China University of Mining and Technology Beijing (CUMTB), has the advantages of constant high resistance and large deformation and has been used successfully in some coal mines [17-20].

In recent years, the traditional bolt-mesh-cable support and bolt support for solving the stability problem of surrounding rock in shallow roadways has been shown to have a certain effect, but under complex geological conditions of high stress and mining action, the deformation of surrounding rock in the deep soft rock roadways is seriously large [21-25]. The traditional supporting mechanism theory and traditional support countermeasures cannot effectively reveal and control the large deformation of the surrounding rock in deep roadways $[8,26,27]$.

Reasonable support countermeasures should be based on the correct evaluation and analysis of the deformation mechanisms of specific roadways [26]. Only in this way can the support materials selected and the support scheme formulated be better targeted and the capital investment and production safety risk coefficient be reduced [27]. Therefore, in view of the nonlinear large deformation problem of deep soft rock roadways, based on the specific engineering geological conditions of deep soft rock roadways, researching causes of the large deformation of deep soft rock roadways, revealing the deformation mechanisms, adopting suitable support materials for deep soft rock roadways, and formulating corresponding countermeasure, are methods that can be used to solve the problem of nonlinear large deformation of deep soft rock roadways [26-28].

The large deformation problem of the surrounding rock in the deep soft roadway in Xin'an coal mine has still been very serious under traditional support countermeasures in recent years. After repeated repairs, large deformation and failure occur in a relatively short time. This seriously restricts the sustainable production of a mine. Based on the engineering background and lessons from previous experience, this paper discusses the nonlinear large deformation mechanism and coupling support countermeasures of a typical deep soft rock roadway. The series of experiments and theoretical analysis presented in this paper reveal in detail the properties, reasons, and mechanism behind the nonlinear large deformation of soft surrounding rock. Based on the experimental results and the deformation mechanism, a suitable coupling support countermeasure is proposed to reduce the nonlinear large deformation and the potential risk during mining. The application shows that the coupling support countermeasures can effectively reduce the nonlinear large deformation of the surrounding rock and help to maintain the stability of the deep soft rock roadways at Xin'an coal mine. It can act as a detailed reference for similar projects in the future. 


\section{Engineering Geological Condition}

\subsection{Project Overview}

Xin'an coal mine is located in Pingliang City, Gansu Province, China (Figure 1). The soft rock roadway discussed in this paper is at a depth of $730 \mathrm{~m}$ and is used to return air.

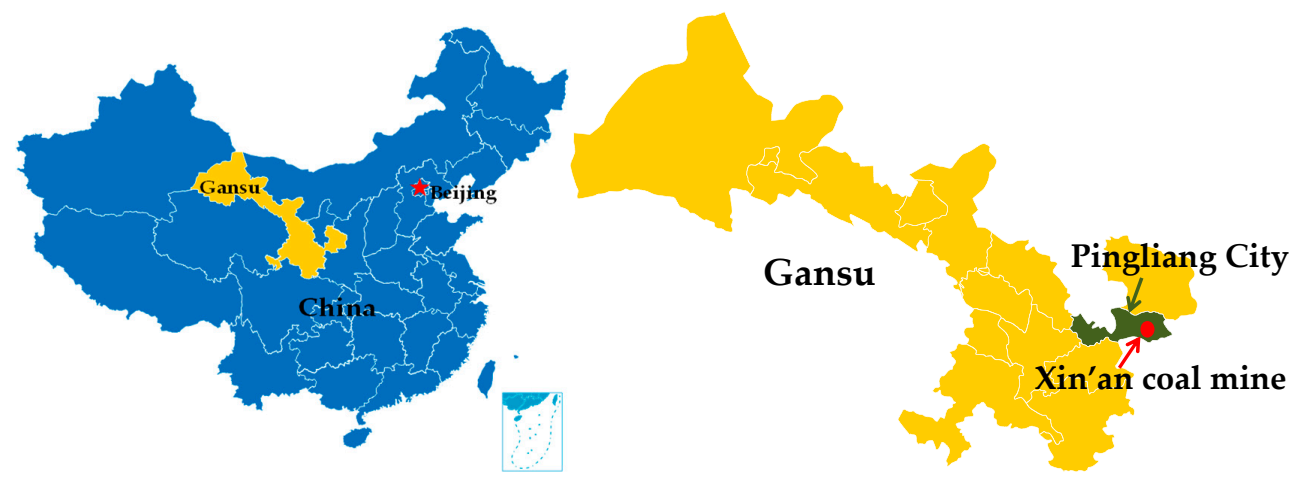

Figure 1. The location of the investigated coal mine.

The overall length of the roadway is $1000 \mathrm{~m}$, and its constructed length is $850 \mathrm{~m}$. During the roadway construction period, there was serious floor heave, side shrinkage, roof subsidence and other problems-typical nonlinear large deformation phenomena. A variety of support forms were adopted in the early excavation and repair support process, including bolt-mesh-shotcrete support, bolt-mesh-cable support, and reinforced concrete support. These traditional support forms were used in an attempt to control the deformation of the surrounding rock to ensure the stability of the roadway, but the effect of the support was not obvious. After repeated repairs, the nonlinear large deformation phenomena, such as roof sinking, shrinkage, floor heave, concrete cracking, and bolt fracture, occurred in a short time,. The failure phenomena seriously restricted the safety and sustainable production of the coal mine.

\subsection{Lithological Analysis of the Surrounding Rock}

The detailed stratigraphic column is described in Figure 2. The layout plan of the roadway is shown in Figure 3.

\begin{tabular}{|c|c|c|c|c|c|}
\hline Column & $\begin{array}{c}\text { Depth } \\
\text { (m) }\end{array}$ & $\begin{array}{l}\text { Elevation } \\
\qquad(\mathrm{m})\end{array}$ & $\begin{array}{l}\text { Thickness } \\
\text { (m) }\end{array}$ & Lithology & Geological description \\
\hline & 717.5 & +547.5 & 5.0 & Mudstone & $\begin{array}{l}\text { Black gray, containing pyritic nodules, gently sloping } \\
\text { horizontal bedding }\end{array}$ \\
\hline & 719.0 & +546.0 & 1.5 & Siltstone & $\begin{array}{l}\text { Grayish green, horizontal bedding, containing thin layer } \\
\text { of mudstone }\end{array}$ \\
\hline & 727.0 & +538.0 & 8.0 & $\begin{array}{c}\text { Sandy } \\
\text { mudstone }\end{array}$ & $\begin{array}{l}\text { Black, containing pyritic nodules, gently sloping } \\
\text { horizontal bedding }\end{array}$ \\
\hline & 733.0 & +532.0 & 6.0 & $\begin{array}{c}\text { Fine } \\
\text { sandstone }\end{array}$ & $\begin{array}{l}\text { Gray or fuchsia, horizontal bedding, containing medium } \\
\text { sandstone }\end{array}$ \\
\hline & 735.0 & +530.0 & 2.0 & Mudstone & $\begin{array}{l}\text { Black gray, containing pyritic nodules, gently sloping } \\
\text { horizontal bedding }\end{array}$ \\
\hline & 736.5 & +528.5 & 1.5 & Siltstone & $\begin{array}{l}\text { Grayish green, horizontal bedding, containing thin layer } \\
\text { of mudstone }\end{array}$ \\
\hline & 739.5 & +525.5 & 3.0 & Mudstone & Gray brown, containing siderite structure \\
\hline
\end{tabular}

Figure 2. Stratigraphic column and geological description at the study site. 


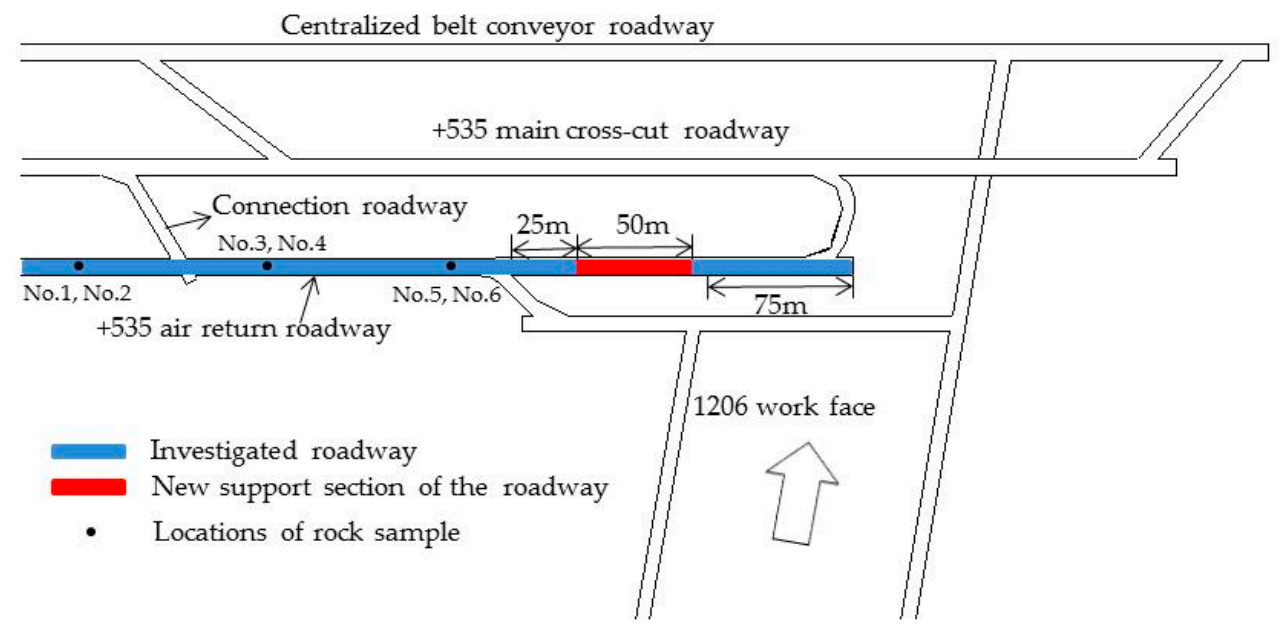

Figure 3. The layout plan of the investigated roadway.

The main surrounding rocks of the roadway were mainly composed of sandy mudstone, mudstone, fine sandstone and siltstone. These strata had a dip angle of nearly 10 degrees. Some rock samples in typical parts of the roadway were selected for laboratory experiments and mechanical parameters were collected. The locations and lithology of the rock samples are shown in Figure 3 and Table 1.

Table 1. The locations and lithology of the rock samples.

\begin{tabular}{clc}
\hline Number & \multicolumn{1}{c}{ Location } & Lithology \\
\hline No. 1 & Roof, $40 \mathrm{~m}$ from the first crossing of the connection roadway & Siltstone \\
No. 2 & Floor, $40 \mathrm{~m}$ from the first crossing of the connection roadway & Mudstone \\
No. 3 & Roof, $35 \mathrm{~m}$ from the first crossing of the connection roadway & Fine sandstone \\
No. 4 & Floor, $35 \mathrm{~m}$ from the first crossing of the connection roadway & Sandy mudstone \\
No. 5 & Roof, $23 \mathrm{~m}$ from the second crossing of connection roadway & Siltstone \\
No. 6 & Floor, $23 \mathrm{~m}$ from the second crossing of connection roadway & Sandy mudstone \\
\hline
\end{tabular}

The strength of the surrounding rock was generally low-among which, the strength of sandy mudstone and silty mudstone was low with an average strength of $8.7 \mathrm{MPa}$, and the average strength of the fine sandstone and siltstone was 14.1 MPa. The rocks all belonged to the category of soft rock, which are unstable rocks. The soft rock has a strong water absorption and the softening coefficient is of a small value. This results in the strength of soft rock decreasing greatly and swelling of rock mass after absorbing water, which are very unfavorable to the stability of the deep soft rock roadway.

\subsection{Clay Mineral Composition Analysis of the Surrounding Rock}

The engineering mechanical properties of soft rock are related to the mineral composition and clay mineral composition. In order to determine the whole rock mineral composition and clay mineral content, X-ray diffraction analysis tests were carried out on rock samples at six typical positions of the roadway (shown in Figure 3 and Table 1). The X-ray diffraction spectrograms of the whole rock minerals of the six rock samples are shown in Figure 4, and the analysis results are shown in Table 2. From Figure 4 and Table 2, it can be concluded that the main mineral components of each rock sample were clay minerals and quartz, and the clay mineral content ranged from $42.1 \%$ to $61.7 \%$, with an average content of $54.5 \%$. The total amount of quartz was from $37.3 \%$ to $57.4 \%$, and the average content was $43.6 \%$. 


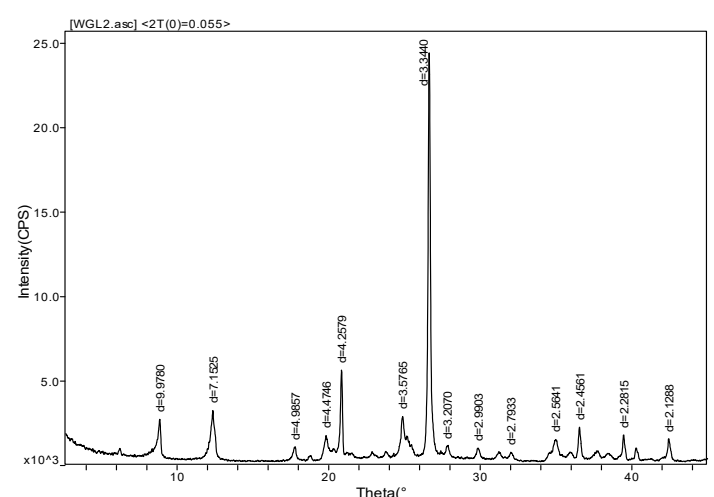

(a)

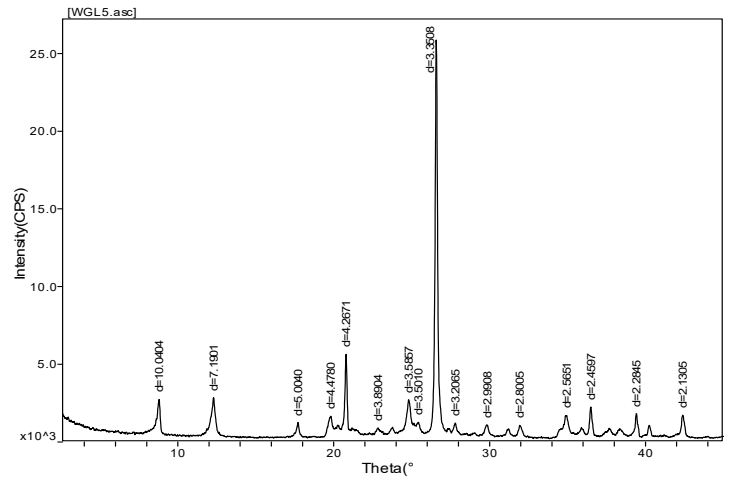

(c)

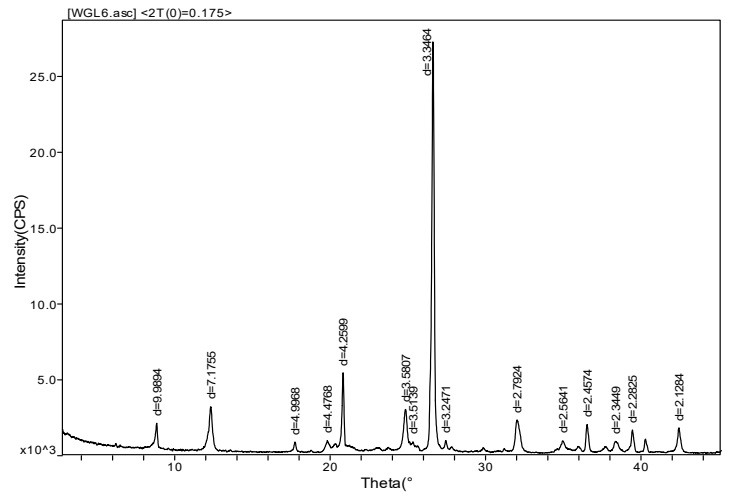

(e)

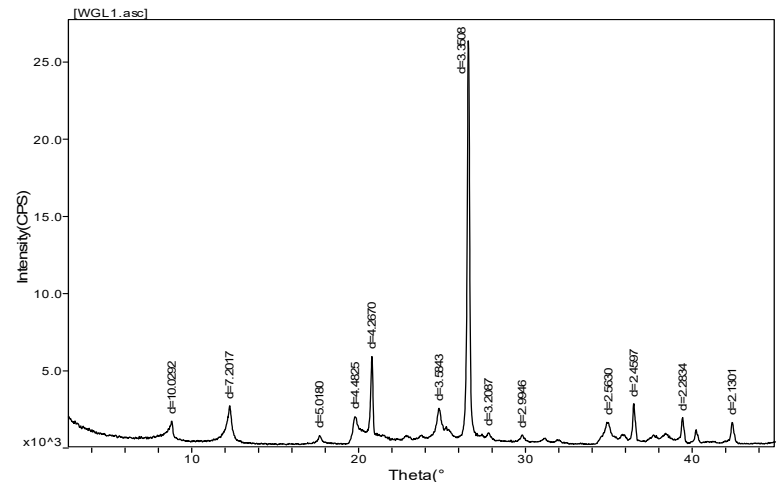

(b)

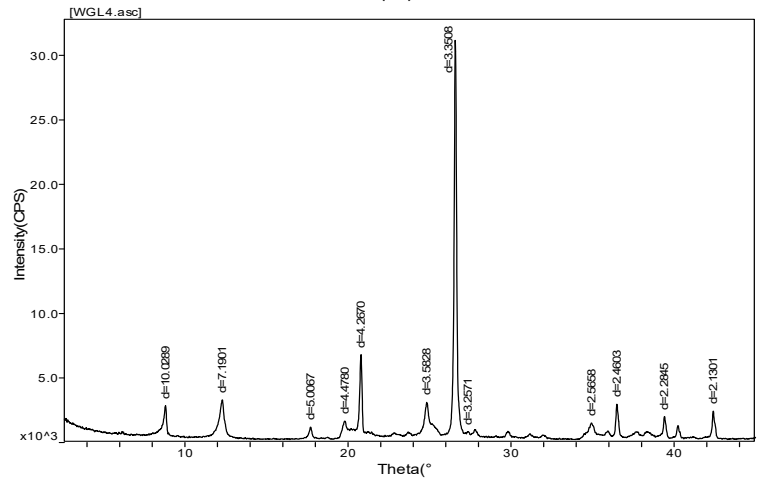

(d)

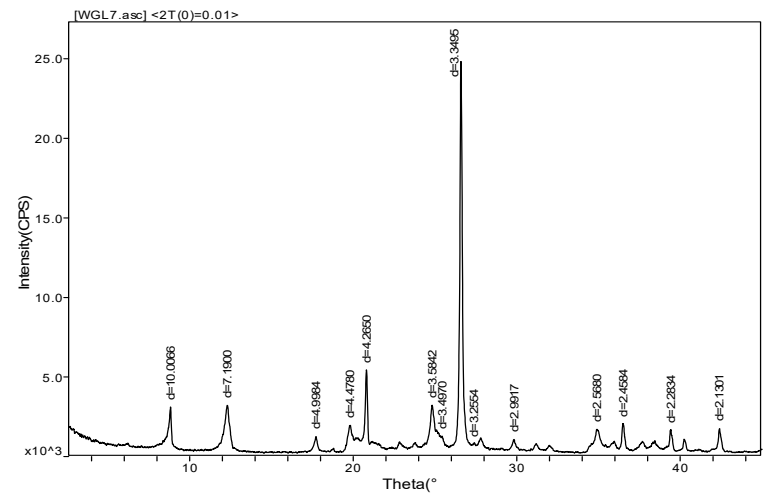

(f)

Figure 4. X-ray diffraction spectrograms of the whole rock mineral: (a) No. 1 siltstone; (b) No. 2 mudstone; (c) No. 3 fine sandstone; (d) No. 4 sandy mudstone; (e) No. 5 siltstone; (f) No. 6 sandy mudstone.

Table 2. The analysis results of the whole rock minerals.

\begin{tabular}{ccccccc}
\hline \multirow{2}{*}{ Number } & \multicolumn{3}{c}{ Species and Content (\%) of Mineral } & \multirow{2}{*}{$\begin{array}{c}\text { Total Clay Mineral } \\
\text { Content (\%) }\end{array}$} \\
\cline { 2 - 5 } & Quartz & Orthoclase & Anorthose & Calcite & Siderite & \\
\hline 1 & 37.9 & 0.5 & $/$ & $/$ & 5.8 & 55.8 \\
2 & 37.3 & 1.0 & $/$ & $/$ & $/$ & 61.7 \\
3 & 57.4 & 0.5 & $/$ & $/$ & $/$ & 42.1 \\
4 & 40.1 & 1.4 & $/$ & 1.6 & $/$ & 56.9 \\
5 & 44.4 & 0.4 & $/$ & $/$ & $/$ & 55.2 \\
6 & 44.3 & 0.3 & $/$ & $/$ & $/$ & 55.4 \\
\hline
\end{tabular}


In order to further study the mineral composition and content of clay minerals, the clay minerals separated from the rock samples were analyzed by $X$-ray diffraction. The X-ray diffraction spectrograms of clay minerals were shown in Figure 5, and the analysis results were shown in Table 3. From Figure 5 and Table 3, it can be concluded that the clay mineral content in the rock sample was mainly kaolinite, followed by smectite and illite. The kaolinite content was from $32 \%$ to $57 \%$, and the average value was $44 \%$. The content of the illite/smectite mixture layer was from $33 \%$ to $47 \%$, and the average value was $39.6 \%$. The illite content was from $10 \%$ to $20 \%$, and the average value was $13.8 \%$.

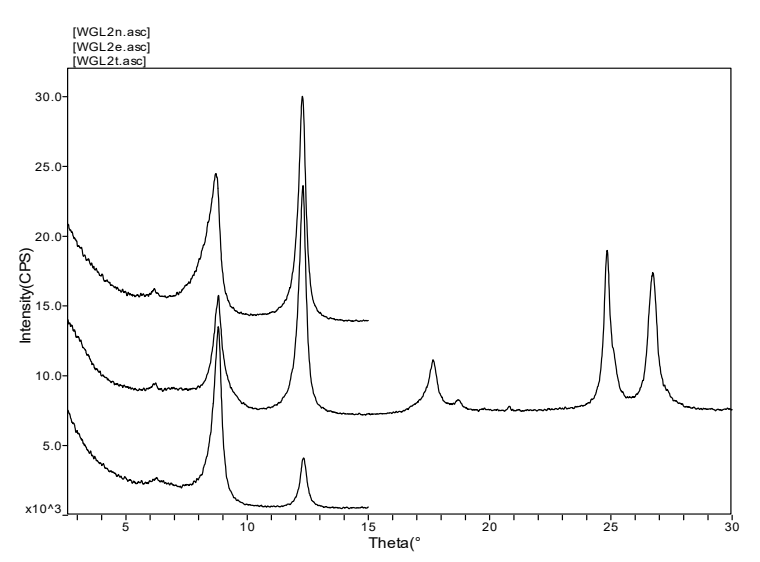

(a)

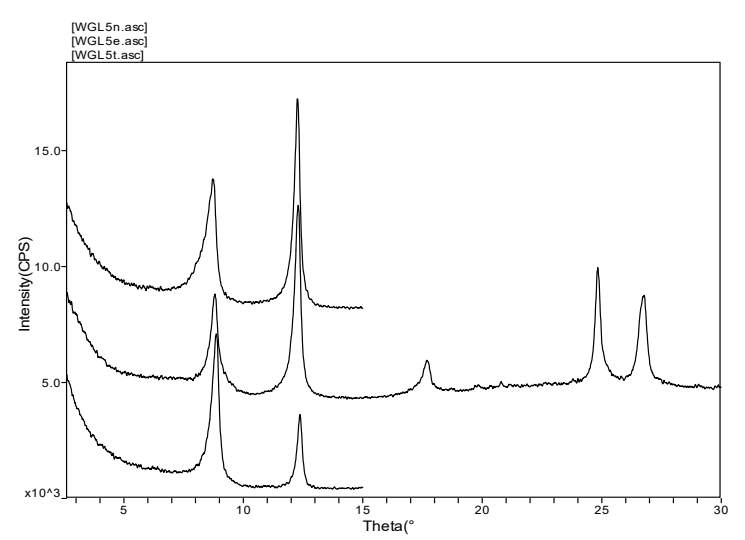

(c)

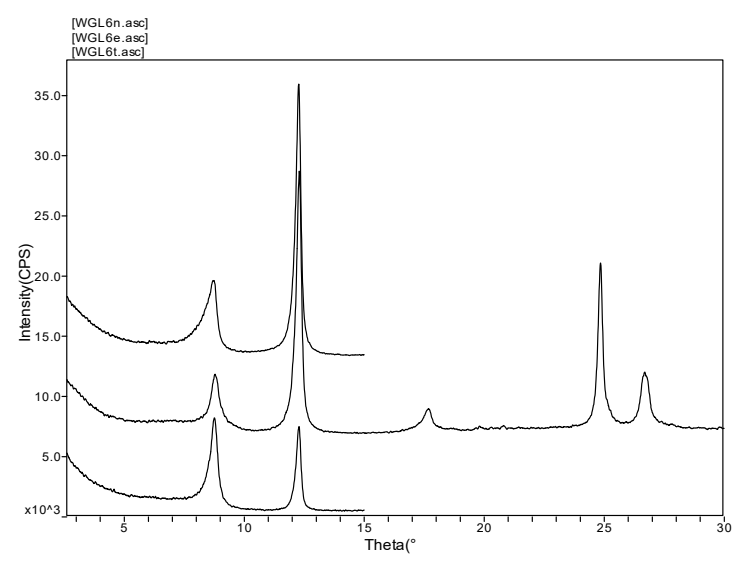

(e)

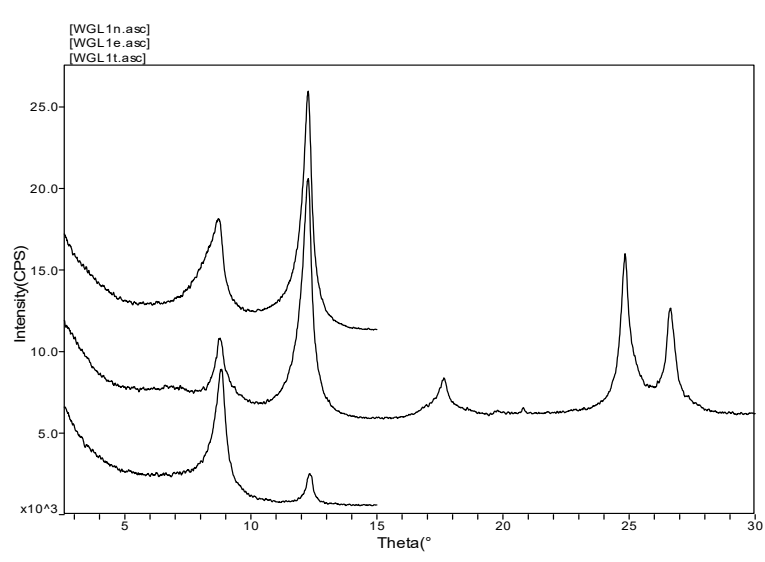

(b)

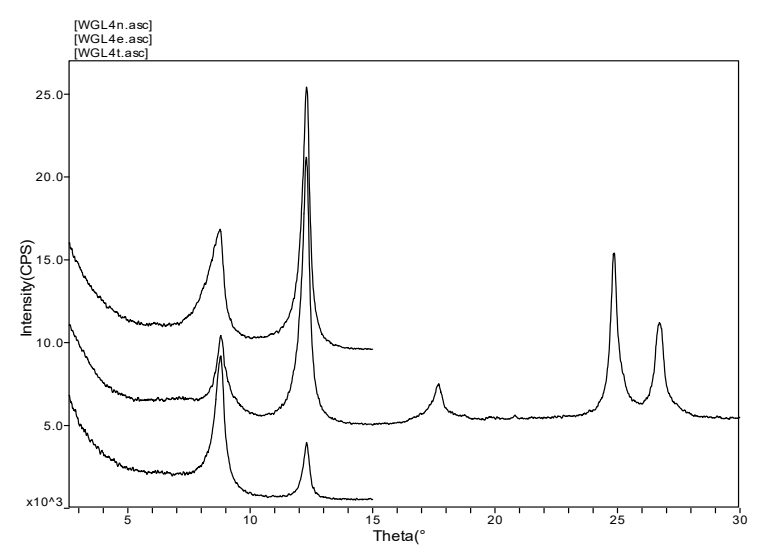

(d)

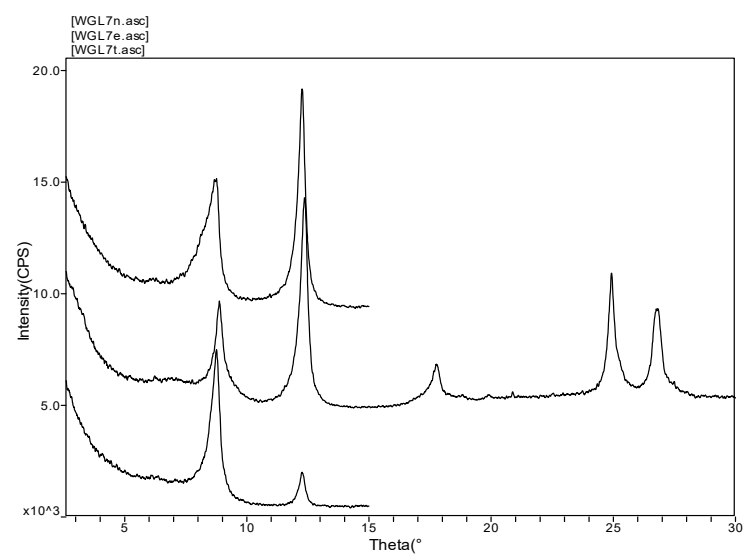

(f)

Figure 5. X-ray diffraction spectrograms of clay minerals: (a) No. 1 siltstone; (b) No. 2 mudstone; (c) No. 3 fine sandstone; (d) No. 4 sandy mudstone; (e) No. 5 siltstone; (f) No. 6 sandy mudstone. 
Table 3. The analysis results of the clay minerals.

\begin{tabular}{|c|c|c|c|c|c|c|c|c|}
\hline \multirow{2}{*}{ Number } & \multicolumn{6}{|c|}{ Relative Contents of the Clay Minerals (\%) } & \multicolumn{2}{|c|}{ Mixture Layer Ratio (S, \%) } \\
\hline & $S^{1}$ & $\mathrm{I} / \mathrm{S}^{2}$ & $I^{3}$ & $K^{4}$ & $C^{5}$ & $C / S^{6}$ & $\mathrm{I} / \mathrm{S}^{7}$ & $\mathrm{C} / \mathrm{S}^{8}$ \\
\hline 1 & / & 39 & 20 & 33 & 8 & / & 35 & / \\
\hline 2 & / & 43 & 10 & 47 & / & / & 35 & / \\
\hline 3 & / & 44 & 15 & 41 & / & / & 35 & / \\
\hline 4 & / & 33 & 10 & 57 & / & / & 35 & / \\
\hline 5 & / & 35 & 11 & 54 & I & I & 35 & I \\
\hline 6 & / & 44 & 17 & 32 & 7 & I & 35 & I \\
\hline
\end{tabular}

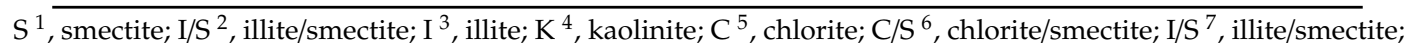
$\mathrm{C} / \mathrm{S}^{8}$, chlorite/smectite.

From the above analysis data, it can be concluded that the rock samples on the roof and floor of the roadway contained a large amount of clay minerals (54.5\%) - among which, kaolinite content had the largest content $(44.5 \%)$, the illite/smectite mixture layer content $(39.6 \%)$ took second place, and the illite content $(13.8 \%)$ was less. These properties are in line with the characteristics of the clay mineral composition of Mesozoic soft rocks. The presence of clay minerals largely determines the mechanical properties of soft rocks. Mesozoic soft rocks contain a large amount of illite/smectite minerals, so their water absorption is obvious and they have strong expansibility and softening. Expansive soft rock is easy to soften, disintegrate, and expand when exposed to water [29,30]. On the one hand, its own strength is greatly reduced. On the other hand, a large expansion force is generated [29-31]. All of these properties of soft rocks are extremely harmful to the stability of the roadway. Therefore, sufficient attention must be paid to the design and construction of the roadway, and corresponding countermeasures should be taken.

\subsection{Microstructural Analysis of the Surrounding Rock}

The reason why soft rocks can produce significant plastic deformation is not only related to clay minerals in rock but also to structural planes in rock. Both of these factors have important influences on the engineering mechanical properties of rock mass [28,32]. The microstructures of deep soft rocks are obviously different from those of similar shallow rocks, which appear to have typical special structural properties [32].

When the No. 1 siltstone sample was magnified by 1980 times, microcracks and surface dissolution holes were observed (Figure 6a). One of the cracks was approximately $25 \mu \mathrm{m}$. When the No. 2 mudstone sample was magnified by 1500 times, a triangular pore and illite/smectite mixture layer arranged in sheets were observed (Figure $6 \mathrm{~b}$ ). The No. 3 fine sandstone sample appeared to have flocculations and a crack at a magnification of 581 times (Figure $6 \mathrm{c}$ ). The width of the crack was approximately $2-5 \mu \mathrm{m}$ with good connectivity. At 1030 times magnification, a disordered bedded arrangement and calcite crystal were seen in the No. 4 sandy mudstone sample (Figure 6d). The No. 5 siltstone sample appeared to be lamellar and had a corrosion crack with a width of approximately $10 \mu \mathrm{m}$ when magnified by 884 times (Figure 6e). When the No. 6 sandy mudstone sample was enlarged by 648 times, many dissolution pores, a big dissolution crack with a length of approximately $100 \mu \mathrm{m}$ and illite/smectite mixture layers were seen (Figure 6f).

Some characteristics of the rock samples were identified from the electron microscope scanning images: (1) the rock samples were found to contain a large number of clay minerals-among which, the kaolinite and illite/smectite mixture layer were mostly disordered structures arranged in sheets and flocculations; (2) there was a large number of dissolution holes on the mineral surface-some of which were filled with argillaceous components and calcite; (3) the microfissures in the rocks were well developed and the connectivity of some fissures was good, with a portion of them filled with calcite and other crystals. 


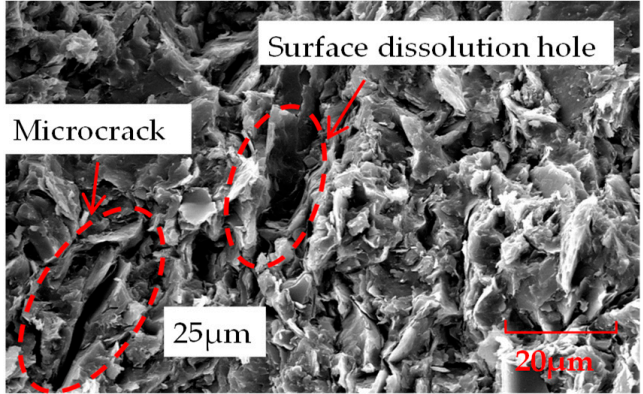

(a)

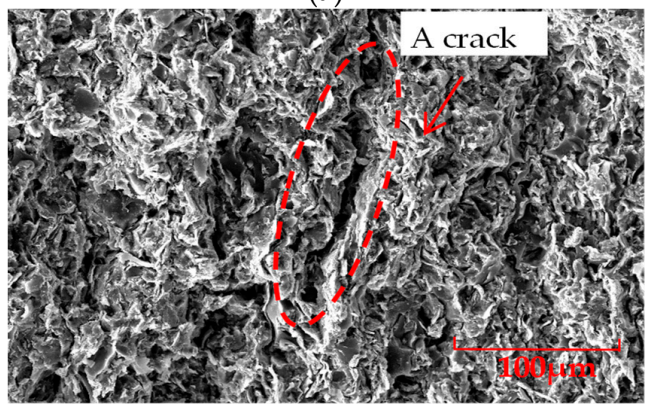

(c)

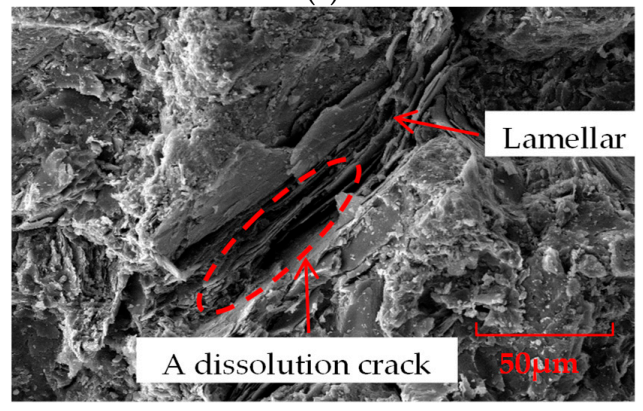

(e)

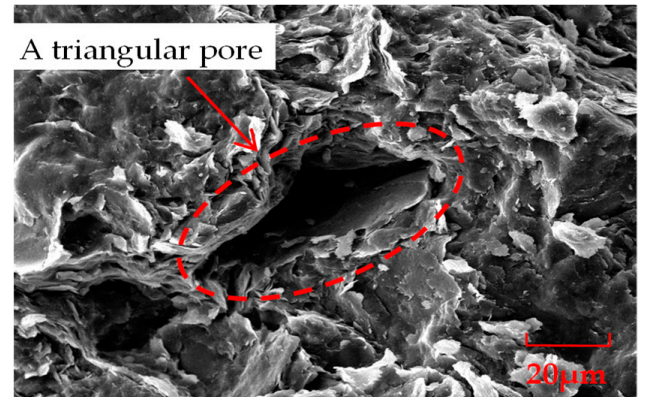

(b)

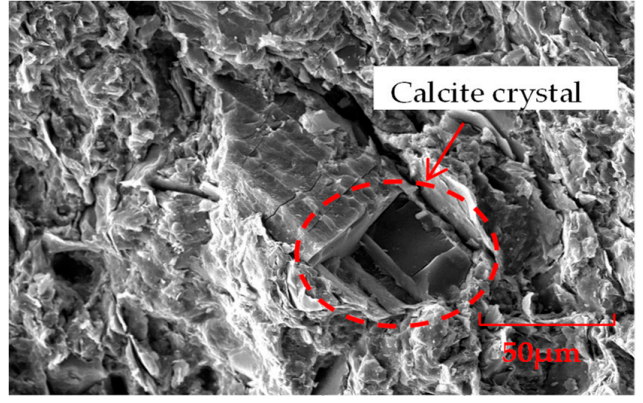

(d)

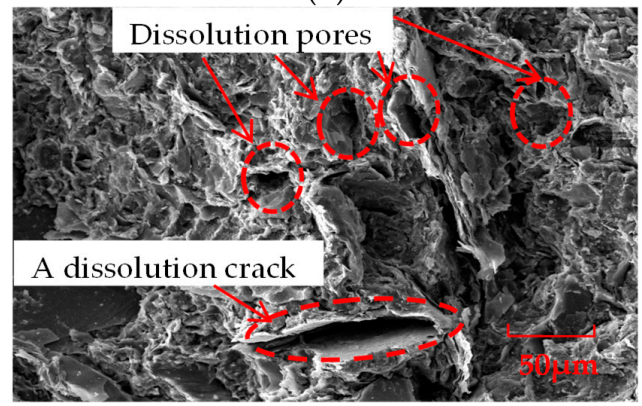

(f)

Figure 6. The electron microscope scanning images of the surrounding rock: (a) No. 1 Siltstone (magnified 1980 times); (b) No. 2 Mudstone (magnified 1500 times); (c) No. 3 Fine sandstone (magnified 581 times); (d) No. 4 Sandy mudstone (magnified 1030 times); (e) No. 5 Siltstone (magnified 884 times); (f) No. 6 Sandy mudstone (magnified 648 times).

\section{Nonlinear Large Deformation Mechanism of the Roadway}

\subsection{Microstructure Analysis of the Surrounding Rock Phenomena and Characteristics of Nonlinear} Large Deformation

A lot of serious failure problems, including floor heave, roof subsidence, side shrink, and damage of support materials, appeared in the roadway under the past support technology. Through field investigation, the nonlinear large deformation characteristics can be summarized as follows:

(1) Serious argillization and desertification of the soft rock: The surrounding rock includes mudstone, siltstone, fine sandstone, and sandy mudstone, which are typical soft rock types with poor strength. The complex environment, including high stress and water during the construction, contributed to the phenomenon of argillization and desertification (see Figure 7a). Sometimes serious argillization of the roof rock formed broken particles, which piled up like a small hill over the floor, as shown in Figure $7 \mathrm{~b}$.

(2) Asymmetrical floor heave deformation: The floor heave was responsible for a large proportion of the deformation in the roadway. The deformation of left floor part was more serious than that of the right floor part, showing the feature of asymmetrical floor heave (see Figure 7c). 
(3) Shear-slip deformation of the roof: After the excavation of the roadway, the vertical stress of the roof fell to zero, and in a horizontal direction, the roadway exhibited a strong lateral extrusion process, which led to shear failure of the rock stratum. The external deformation processes were the fragmentized stripping of the left spandrel of the roof (Figure $7 \mathrm{~b}$ ), a serious sinking area, clear relative dislocation displacement, and inward extrusion, as shown in Figure $7 \mathrm{~d}$.

(4) Asymmetrical shrinkage of the side walls: There is a lot of fractured rock, which has persistent rheological properties under a complex environment. Because of the different angles between the rock and the side walls of the roadway, the rock of the side walls underwent dislocation and inward extruding deformation to different degrees. Consequently the side walls presented asymmetrical shrinkage, as shown in Figure 7e.

(5) Damage to support materials. The concrete spray layer on the surface of the surrounding rock fractured and spalled over large area. Many steel meshes, rock bolts, and rock cables were destroyed so that they were unable to support the roadway, as shown in Figure 7f. These support materials used in the old support technology were evidently unsuitable for the deformation of the roadway.

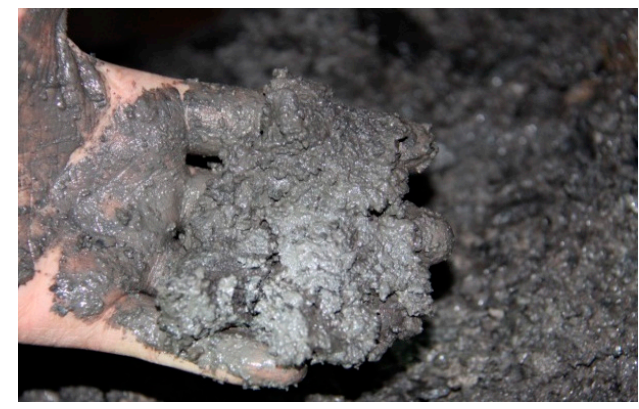

(a)

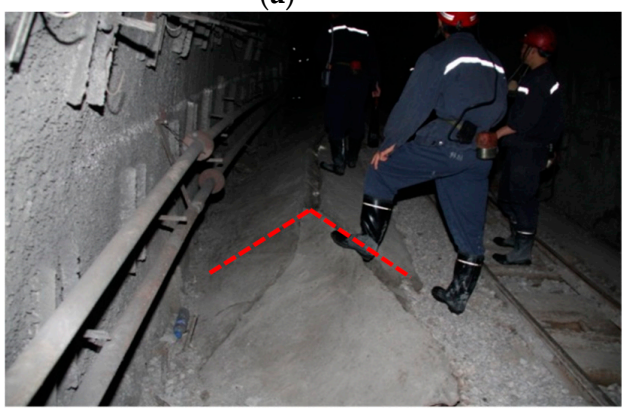

(c)

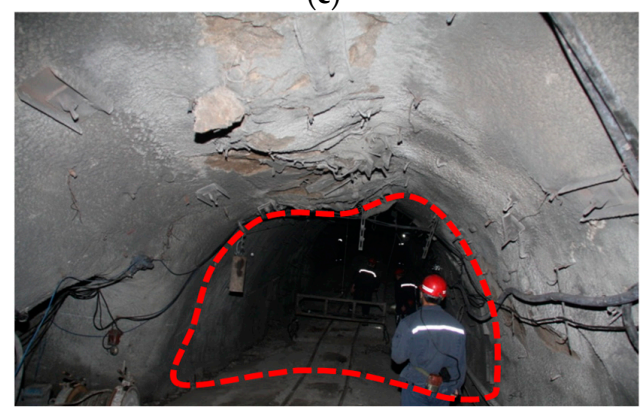

(e)

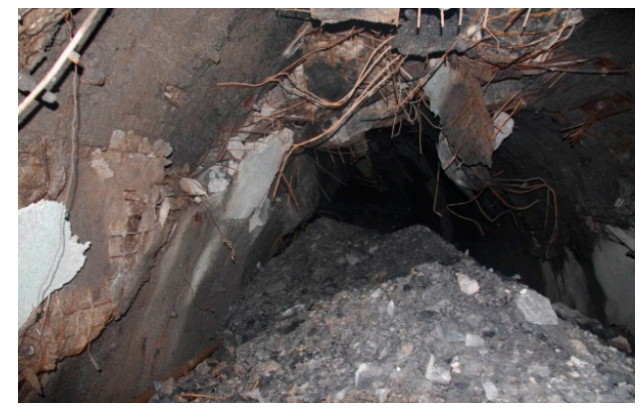

(b)

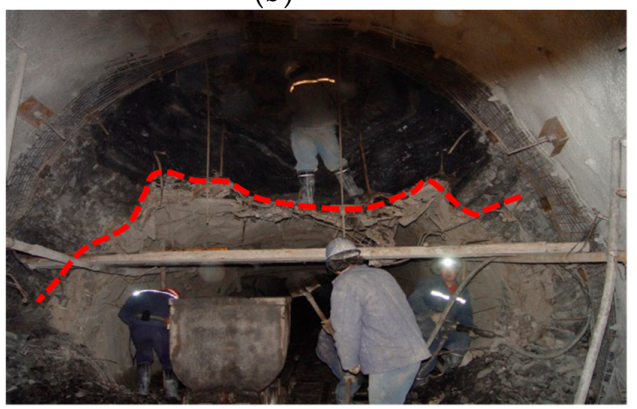

(d)

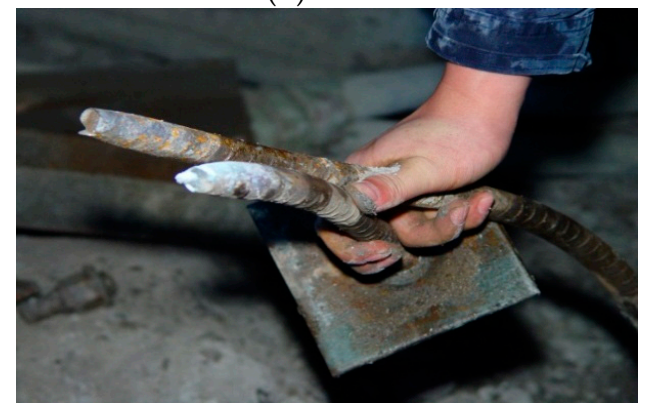

(f)

Figure 7. Failure phenomena of the roadway: (a) Argillization and desertification of the soft rock; (b) Broken particles of left spandrel of the roof piling up like a small hill over the floor; (c) Asymmetrical floor heave; (d) Serious sinking area; (e) Asymmetrical shrinkage of the section of the roadway; (f) Damage to support materials. 


\subsection{Type of Nonlinear Large Deformation Mechanism}

Researchers investigating the deformation mechanism of soft rock roadways generally adopt the typical classification method proposed by professor Manchao He [26,33]. Based on a field engineering geology study, laboratory physical and chemical mechanics test analyses, and a theoretical analysis, the deformation mechanism type of the soft rock roadway can be determined correctly $[26,27,33]$. There are three main types: Type I, Type II, and Type III. Type I is mainly confirmed according the typical minerals and microfracture development situation of the surrounding rock. Type II is mainly determined by the mechanical characteristics and the fracture features of the roadway under engineering force. Type III is based on the mechanical properties of the structural plane, structural system, and crosscutting relation between the occurrence and the roadway strike.

In the detailed classification of Type I, different types have different controlling factors and characteristics. The factor controlling Type $\mathrm{I}_{\mathrm{A}}$ is a molecular water absorption mechanism typically with smectite. The factor controlling Type $\mathrm{I}_{\mathrm{B}}$ is a colloidal water absorption mechanism typically with kaolinite. The common characteristic is extensive expansion after water absorption. The mineral composition of the surrounding rock has a large portion of clay minerals, especially the kaolinite (44.5\%) and illite/smectite mixture layer contents (39.6\%). The rock also appears to have strong expansibility. So, in Type $\mathrm{I}$, the deformation mechanism includes Type $\mathrm{I}_{\mathrm{A}}$ and Type $\mathrm{I}_{\mathrm{B}}$, namely Type $\mathrm{I}_{\mathrm{AB}}$. In the detailed classification of Type II, there are four branch types: Type $\mathrm{II}_{\mathrm{A}}$, Type $\mathrm{II}_{\mathrm{B}}$, Type $\mathrm{II}_{C}$, and Type $\mathrm{II}_{\mathrm{D}}$. They correspond, respectively, to the four main controlling factors: tectonic stress, gravitational stress, water stress, and engineering deviatoric stress. The stresses acting on this roadway are mainly tectonic stress in the near horizontal direction and gravitational stress in the vertical direction. At the same time, the roadway is very close to other roadways, which contain previous engineering deviatoric stress. All of the stress fields are superimposed onto each other. Therefore, in Type II, the deformation mechanism includes Type $\mathrm{II}_{\mathrm{A}}$, Type $\mathrm{II}_{\mathrm{B}}$, and Type $\mathrm{II}_{\mathrm{D}}$, namely, Type $\mathrm{II}_{\mathrm{ABD}}$. In the detailed classification of Type III, there are six branch types, Type $\mathrm{III}_{\mathrm{A}}$, Type $\mathrm{III}_{\mathrm{B}}$, Type $\mathrm{III}_{\mathrm{C}}$, Type $\mathrm{III}_{\mathrm{D}}$, Type $\mathrm{III}_{\mathrm{E}}$, and Type $\mathrm{III}_{\mathrm{F}}$. They correspond, respectively, to the six main controlling factors: the fault, weak intercalated layer, bedding, dominant joint, and random joint. The surrounding rock mass contains previous weak intercalated layer and bedding. So, in Type III, the deformation mechanism contains Type $\mathrm{III}_{\mathrm{B}}$ and Type $\mathrm{III}_{\mathrm{C}}$, namely Type $\mathrm{III}_{\mathrm{BC}}$.

Therefore, the overall deformation mechanism of the roadway can be taken as the composite mechanism, namely, Type $\mathrm{I}_{\mathrm{AB}} \mathrm{II}_{\mathrm{ABD}} \mathrm{III}_{\mathrm{BC}}$.

\subsection{Transformation of Nonlinear Large Deformation Mechanism}

Based on the composite mechanism type of the soft rock roadway, the corresponding mechanical countermeasures, which could transform composite deformation mechanism into a simple one, should be selected to ensure the stable support of the roadway $[26,27,34]$. The available mechanical countermeasures corresponding to every typological deformation mechanism are shown in the following text:

(1) Type $\mathrm{I}_{\mathrm{AB}}$ : To control the typical expansion deformation energy of the surrounding rock of roadway, the CRLD bolt can be used to hierarchically release the deformation energy.

(2) Type $\mathrm{III}_{\mathrm{BC}}$ : In order to deal with the influences of weak intercalated layers and bedding, the three-dimensional optimization technique of the bolt and key position support technique can be combined [26,27].

(3) Type $\mathrm{II}_{\mathrm{ABD}}$ : The bolt-mesh coupling support technique and floor hollow grouting cable technique could be used in combination to cope with the complex influences of tectonic stress, gravity stress and engineering deviatoric stress.

The whole transformation process can be summarized into three steps:

(1) First step: The CRLD bolt absorbs the energy released by surrounding rocks through deformation and gives full play to its mechanical properties of constant resistance and large deformation. 
Through the support methods, the composite mechanism of Type $\mathrm{I}_{\mathrm{AB}} \mathrm{II}_{\mathrm{ABD}} \mathrm{III}_{\mathrm{BC}}$ can be transformed to Type $\mathrm{II}_{\mathrm{ABD}} \mathrm{III}_{\mathrm{BC}}$.

(2) Second step: CRLD bolts with a length of $6 \mathrm{~m}$ can be applied to the key parts to effectively control the large deformation of the key parts, and floor hollow grouting cables are applied to strengthen the support strength of the bottom corners of the floor. Through the methods, the unstable mechanism of Type $\mathrm{II}_{\mathrm{ABD}} \mathrm{III}_{\mathrm{BC}}$ can be transformed to Type $\mathrm{II}_{\mathrm{ABD}}$.

(3) Third step: The coupling role of the bolt and steel mesh could improve the supporting force. The floor hollow grouting cable could improve support strength of the floor. Multiple support countermeasures could play a supporting role to transform the unstable deformation mechanism into a simple Type $\mathrm{II}_{\mathrm{B}}$ one.

The detailed transformation process is shown in Figure 8.

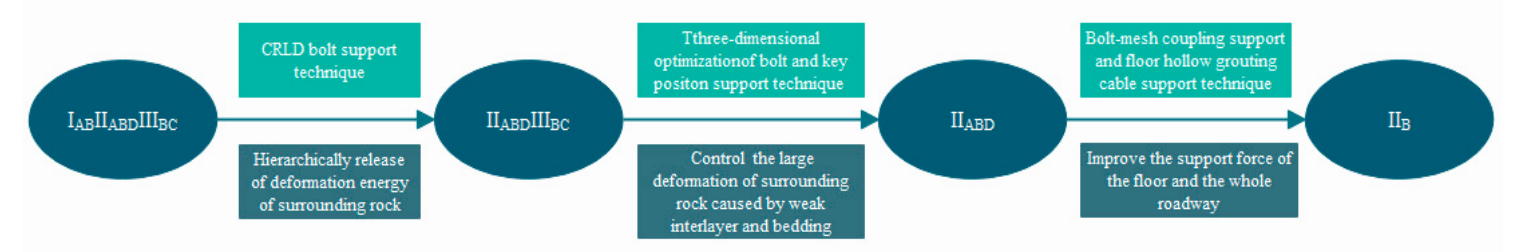

Figure 8. Transformation process of the composite deformation mechanism.

\section{Stability Control Countermeasures and Application}

\subsection{Mechanical Properties of the CRLD Bolt}

A diagrammatic drawing of the CRLD bolt adopted in the study is shown in Figure 9. A CRLD bolt is mainly composed of a nut, a pallet, a constant resistance device (CR device), a connection fitting, and a connecting rod $[15,17,18]$, as shown in Figure 9. The CR device includes a rod and a sleeve pipe. The cone part of the rod is located at one end of the rod inside the sleeve pipe. The other end of the rod is the connecting part, which can be combined with the connecting rod through the connection fitting. Typical features of the CRLD bolt are the provision of constant resistance and large deformation during the stretching process. A lot of stretch experiments of the CRLD bolts were performed. An experimental curve is shown in Figure 10. We can see from Figure 10 that the bolt had a constant stretching force of approximately $175 \mathrm{kN}$ and a large deformation of approximately $750 \mathrm{~mm}$. During the stretching process, it can absorb energy through deformation. Additionally, the absorbed energy can be calculated through the experiment data, as shown in Table 4. The special properties of the CRLD bolt can be summarized as shown in Table 4, which can adapt to the needs of the support materials used in soft rock roadways.

Table 4. The mechanical properties of CRLD bolt.

\begin{tabular}{cccc}
\hline Properties & $\begin{array}{c}\text { Constant Resistance/Constant } \\
\text { Stretching Force }\end{array}$ & Large Deformation & Absorbing Energy \\
\hline Average value (Figure 10) & $130 \mathrm{kN}$ & $750 \mathrm{~mm}$ & $135.24 \mathrm{~kJ}$ \\
\hline
\end{tabular}

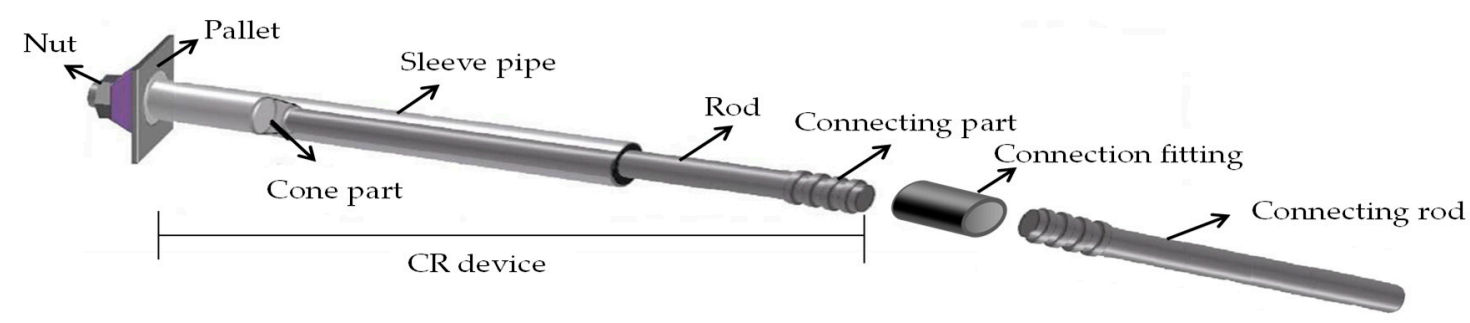

Figure 9. Diagrammatic drawing of a Constant Resistance Large Deformation (CRLD) bolt. 


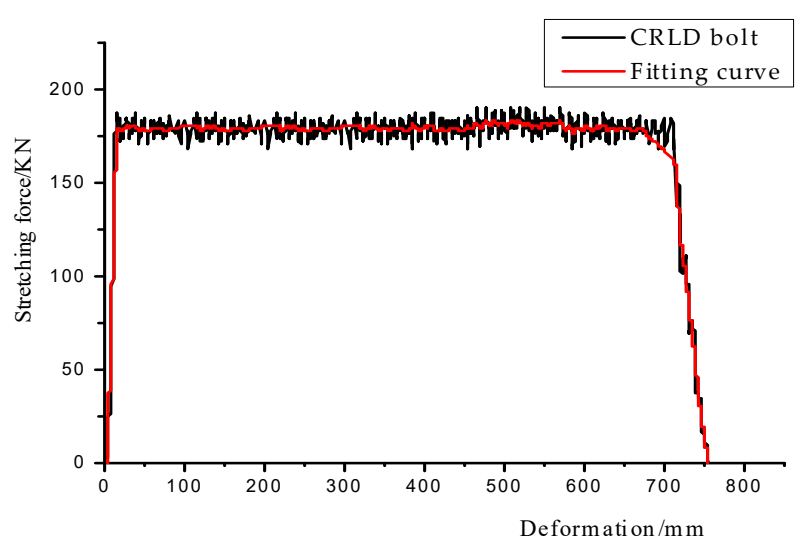

Figure 10. Stretching force and deformation curve in the stretching experiment of the CRLD bolt.

\subsection{Support Design of the Soft Rock Roadway}

\subsubsection{Support Countermeasure of the New Support Countermeasure}

Based on the transformation process and corresponding mechanical countermeasures of the composite mechanism type of the soft rock roadway, the new coupling support countermeasure of CRLD bolt + steel mesh + floor hollow grouting cable + steel fiber concrete was proposed. The CRLD bolt can hierarchically release the deformation energy to control the typical expansion deformation energy of the surrounding rock of the roadway. The combination of bolt and mesh can cope with the influences of weak intercalated layers and bedding. Additionally, the use of the floor hollow grouting cable could effectively enforce the stability of floor and decrease the floor heave. The use of steel fiber concrete could further improve the integrity of the roadway. The coupling use of these support materials based on deformation mechanism could provide more effective support advantages and improve the stability of the roadway.

\subsubsection{Sectional Form of the Roadway}

The section form of the roadway was a straight wall semicircle arch. The net width of the section was $4300 \mathrm{~mm}$. The net arch highness was $3550 \mathrm{~mm}$. The net radius of the semicircle arch was $2150 \mathrm{~mm}$. The height of the straight wall was $1400 \mathrm{~mm}$. The baseline of the arch overlaped with the waistline.

\subsubsection{Support Materials and Parameters of the New Support Countermeasure}

1. Bolt: Two sizes of CRLD bolts with a rod diameter of $22 \mathrm{~mm}$ were adopted, one with a length of $3000 \mathrm{~mm}$ and the other one with a length of $6000 \mathrm{~mm}$. Furthermore, the diameter of the bolt drill bit was $36 \mathrm{~mm}$ and the diameter of the drill hole was not less than $38 \mathrm{~mm}$. The inter-row space was $1000 \times 1000 \mathrm{~mm}$ between each CRLD bolt, and the bolts were arranged in parallel. Additionally, capsule resin was used inside the drill hole for the fixation of the bolt.

2. Floor hollow grouting cable: Three floor hollow grouting cables with a length of $6000 \mathrm{~mm}$ were arranged in each base angle. The inter-row space was $1000 \times 400 \mathrm{~mm}$ between each cable, and the cables were arranged in parallel.

3. Steel mesh: The steel mesh is welded from many steels with a diameter of $8.0 \mathrm{~mm}$. A piece of steel mesh consists of many small square grids. The regular size of a piece of steel mesh was $1700 \mathrm{~mm} \times 2500 \mathrm{~mm}$. And the size of each small grid was $100 \mathrm{~mm} \times 100 \mathrm{~mm}$. The steel meshes were connected through special steel hooks. The distance between steel hooks was less than $200 \mathrm{~mm}$. And the connection part of steel meshes was overlapped each other. The length of overlapping part of a piece of steel mesh is $100 \mathrm{~mm}$.

4. Concrete: Steel fiber concrete with water-repellent admixture was adopted. The strength of the concrete was C20. 


\subsubsection{Construction Process of the New Support Countermeasure}

The overall sectional support design and expansion graph of the proposed roadway are shown in Figures 11 and 12.

The detailed construction process is as follows:

1. First support: Based on the designed straight wall semicircle arch, excavate and ensure there is a good shape, firstly spray steel fiber concrete with a thickness of $60 \mathrm{~mm}$, hang mesh, and install CRLD bolts with a length of $3000 \mathrm{~mm}$, as shown in Figure 11a.

2. Second support: Based on the first support, secondly, spray steel fiber concrete with a thickness of $40 \mathrm{~mm}$, install CRLD bolts with the length of $6000 \mathrm{~mm}$; and spray steel fiber concrete with a of thickness of $40 \mathrm{~mm}$, as shown in Figure 11b.

3. Third support: Based on the second support, excavate the floor, spread concrete with a thickness of $140 \mathrm{~mm}$, hang the floor mesh, drill the cable hole, and install the floor hollow grouting cables, as shown in Figure 11c.

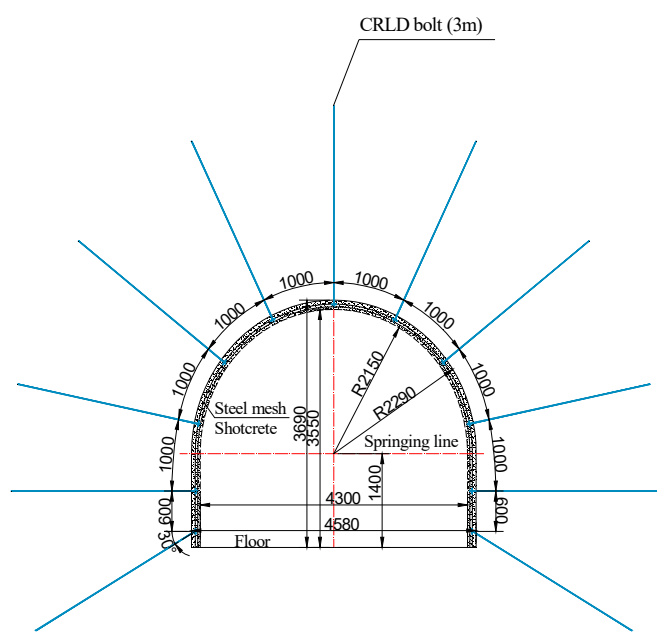

(a)

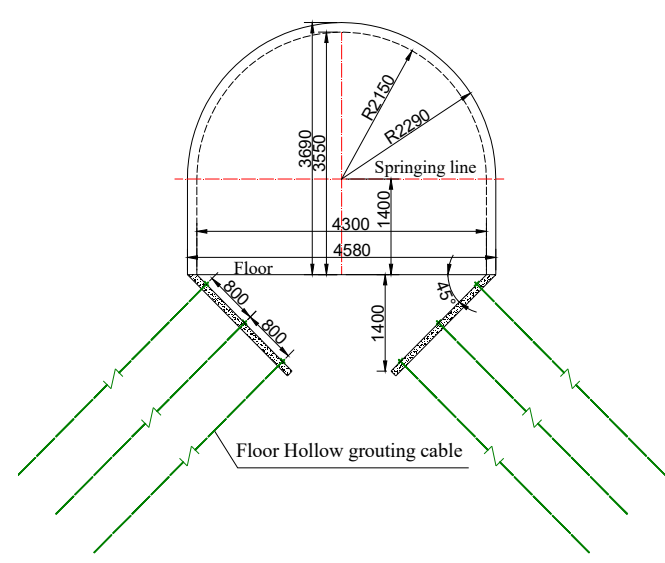

(c)

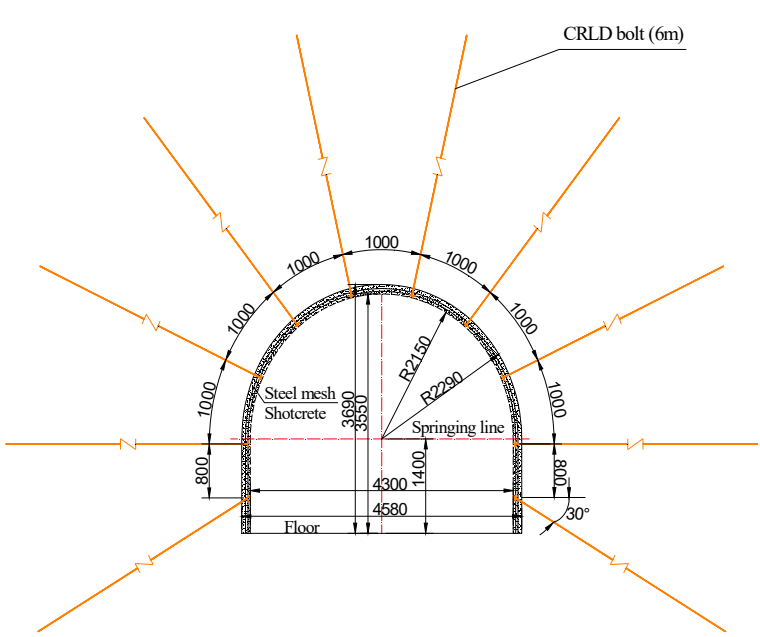

(b)

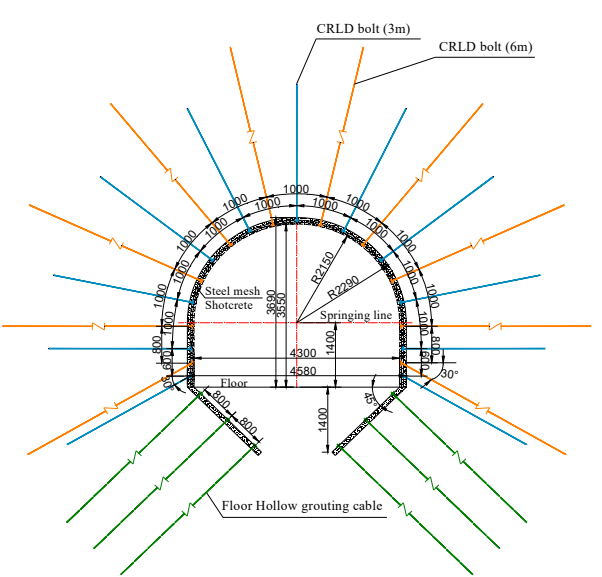

(d)

Figure 11. Sectional support design and construction process of the new support countermeasure: (a) First support; (b) Second support; (c) Third support; (d) Overall sectional support design of the roadway.

Because of the use of CRLD bolt, the strain energy of surrounding rock is released effectively, and part of the stress is transferred to the deep rock stratum. Because of the use of the floor hollow 
grouting cable, the floor base angle part is reinforced, cutting off the transformation of horizontal stress to the floor. Additionally, the uniform distribution of the floor stress could reduce the concentrated stress region of shallow stratum on the floor and transform the concentration stress region to deep rock stress. The coupling effects of these support materials would provide an effective support force on the stability of the deep soft rock roadway.

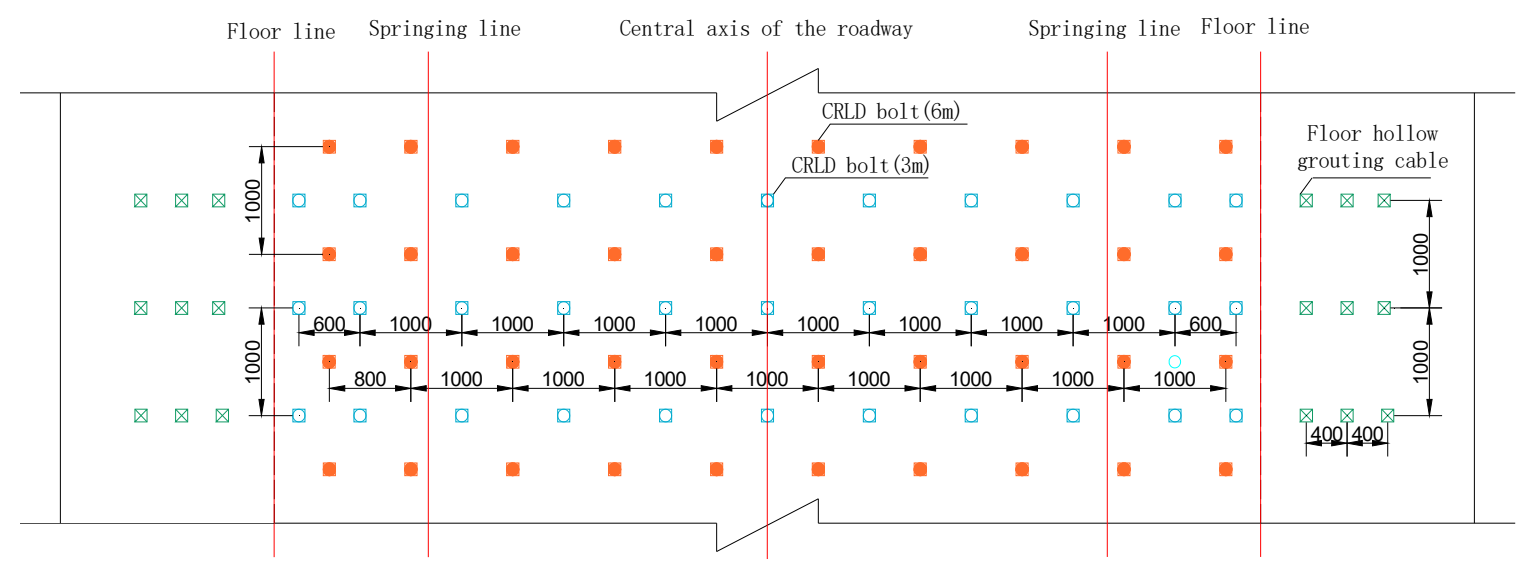

Figure 12. Sectional expansion graph of the new support design.

\subsubsection{Support Design of the Old Support Countermeasure}

In the other section of the roadway, the old support countermeasure of bolt-mesh-cable support was wtill adopted. The bolts were regular rebar bolts with the diameter of $22 \mathrm{~mm}$. The inter-row space was $750 \times 750 \mathrm{~mm}$ between each bolt, and the bolts were arranged in parallel. The inter-row space of the cables was $1500 \times 1500 \mathrm{~mm}$ between each cable. The sectional support design of the old support countermeasure is shown in Figure 13.

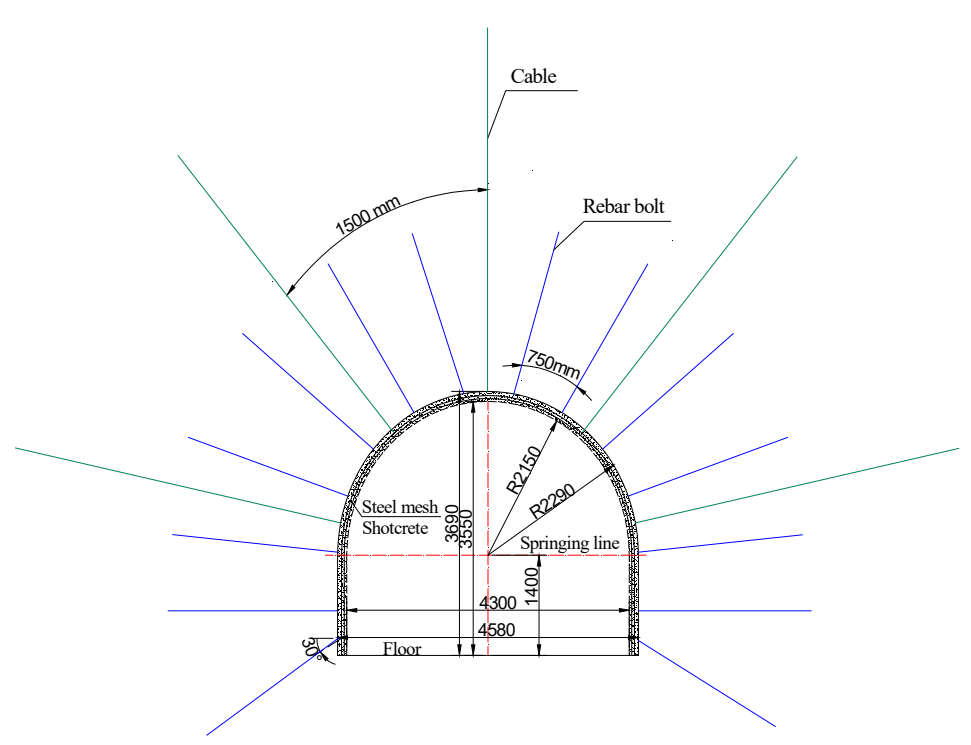

Figure 13. Sectional support design of the old support countermeasure.

\subsection{Support Effect of the New Support Countermeasure}

In order to test the effectiveness of the support design, the deformation situation of the surrounding rock of the roadway was monitored after adopting the new support design. Four monitoring points along the new support test section of the roadway were chosen for tracking, and two monitoring points were chosen for tracking, as shown in Figure 14. 


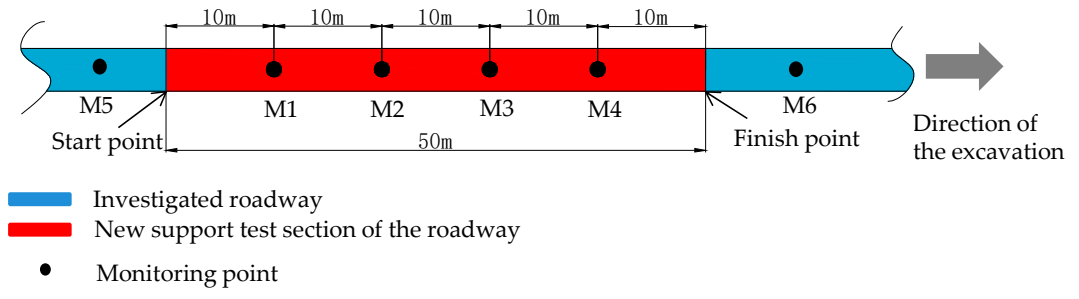

Figure 14. Layout plan of the monitoring points of the roadway.

The deformation of the roadway surface of the four points during the new support test section are shown in Figure 15. Through the deformation monitoring curve of the four points, we were able to divide the deformation process of the surrounding rock into three stages:

1. First stage: active stage. From the fourth day to the twentieth day after excavation, the deformation velocity of the surrounding rock was fast. Additionally, the total deformation value was the biggest. During this stage, the surrounding rock was in an active state from the stable state before excavation.

2. Second stage: transitional stage. From the twentieth day to the eightieth day after excavation, the deformation velocity of surrounding rock became slower. Additionally, the total deformation value of the surrounding rock became progressively smaller than in the first stage. During this stage, the deformation of the surrounding rock showed a stable trend.

3. Third stage: stable stage. After the eightieth day, the deformation velocity of the surrounding rock gradually reduced to zero. The total deformation of the surrounding rock reached a stable value. Additionally, the surrounding rock reached a stable state again after two stages of deformation.

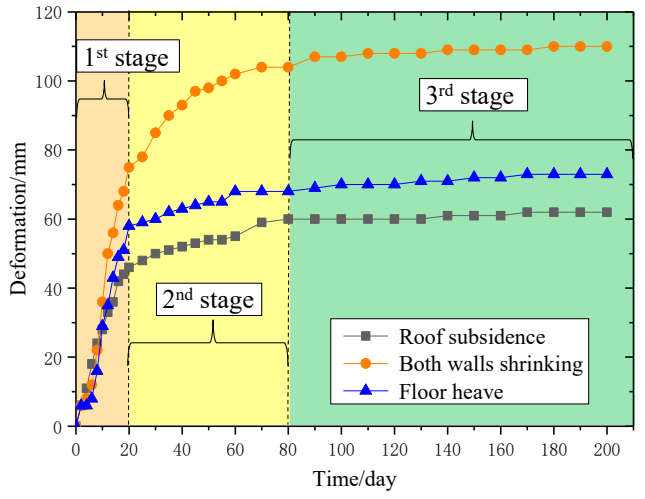

(a)

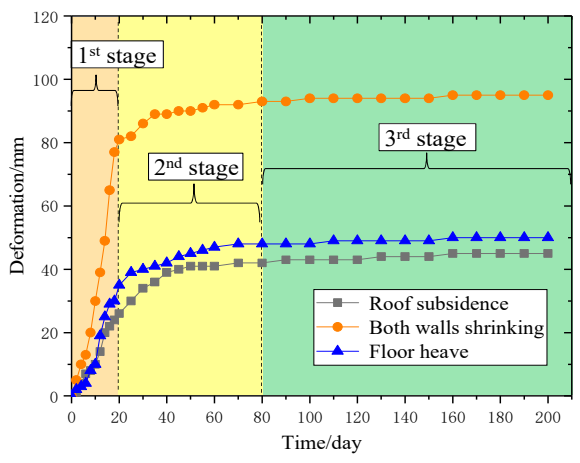

(c)

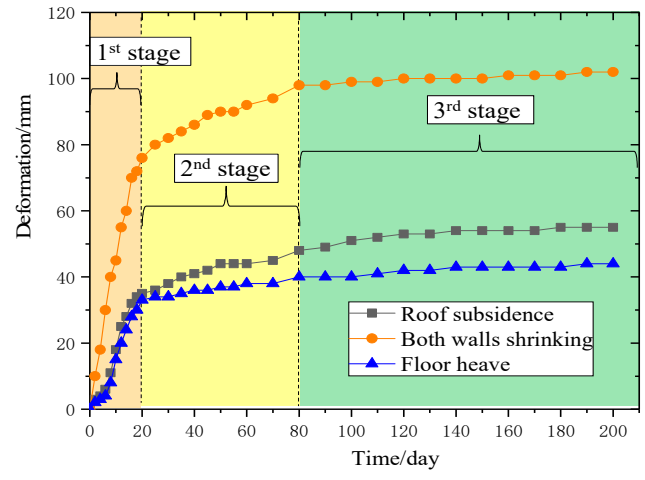

(b)

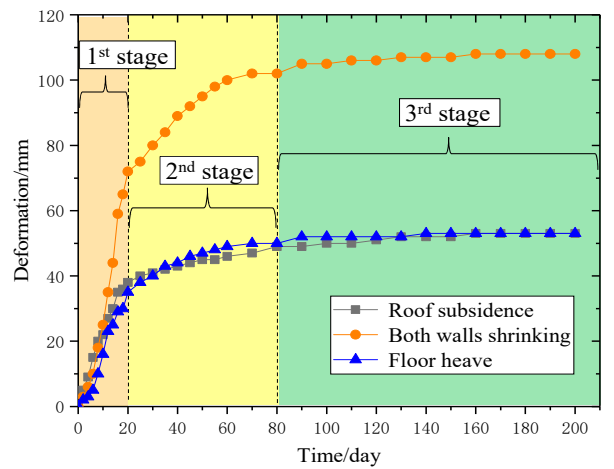

(d)

Figure 15. Deformation and time curves of monitoring points under the new support countermeasure: (a) Monitoring point M1; (b) Monitoring point M2; (c) Monitoring point M3; (d) Monitoring point M4. 
From the monitoring data shown in Figure 15, some results about the deformation value of the roadway can be concluded. The average deformation of the roof subsidence of the four monitoring points was approximately $52 \mathrm{~mm}$. The average deformation of the floor heave was approximately $55 \mathrm{~mm}$. Since the average shrinking value of the two walls was approximately $104 \mathrm{~mm}$, the average deformation of one wall was approximately $52 \mathrm{~mm}$. So the deformation of the four directions (roof, floor, and two walls) of a section of the roadway was uniform-approximately $53 \mathrm{~mm}$.

The deformation of the roadway surface of the two points under the old support countermeasure is shown in Figure 16. Through the deformation monitoring curve of the two points, we can see that the average deformation of the roof subsidence was approximately $392 \mathrm{~mm}$, the average deformation of the floor heave was approximately $479 \mathrm{~mm}$, and the average shrinking value of the two walls was approximately $580 \mathrm{~mm}$.

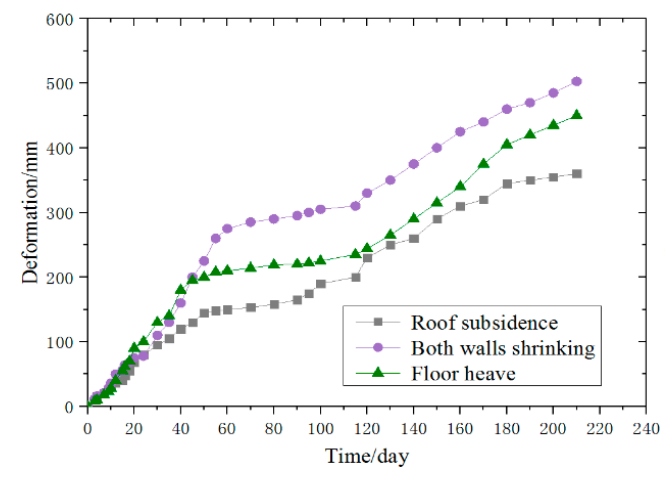

(a)

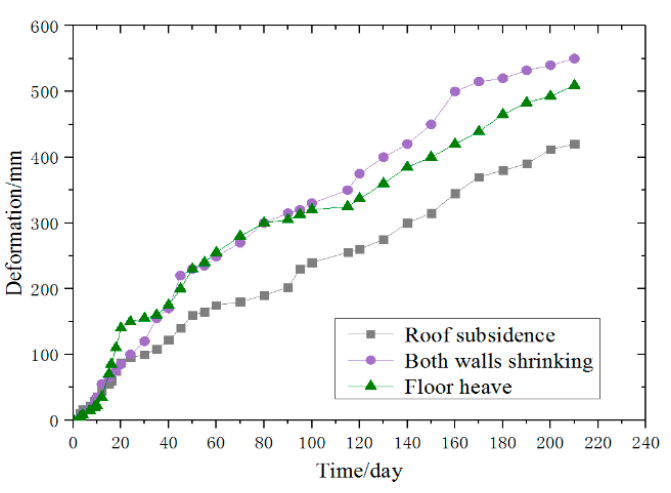

(b)

Figure 16. Deformation and time curves of two monitoring points under the old support countermeasure:

(a) Monitoring point M5; (b) Monitoring point M6.

Through the comparison of deformation values shown in Figures 15 and 16, we found that the total deformation value under the new support countermeasure was far less than the deformation value under the old support countermeasure. So, from the aspect of deformation of the surrounding rock in the test section, the new proposed coupling support countermeasure can effectively control the nonlinear large deformation of the surrounding rock of the roadway.

Along with the deformation of surrounding rock, the CRLD bolt also produced the stretching phenomenon. To further observe the deformation situation of the CRLD bolt, the tensile deformation of each CRLD bolt in the test section was measured and recorded. In the test section, there were 50 rows of bolts-the sequence of which is shown in Figure 17a. The arrangement and number of each row of bolts in the first support and second support are shown in Figure 17b,c.

The deformation of each CRLD bolt is shown in Figure 18. From Figure 18, we can see that the 50 rows of bolts all had some deformation values. Figure 18a shows the average deformation value of the bolts installed on the left wall in the first support was approximately $53.1 \mathrm{~mm}$. The average deformation value of bolts installed on the roof in the first support was approximately $52.6 \mathrm{~mm}$, as shown in Figure 18b. The average deformation value of the bolts installed on the right wall in the first support was approximately $50.7 \mathrm{~mm}$, as shown in Figure 18c. Figure 18d shows that the average deformation value of the bolts installed on the left wall in the second support was approximately $53.3 \mathrm{~mm}$. The average deformation value of the bolts installed on the roof in the second support was approximately $52.3 \mathrm{~mm}$, as shown in Figure 18e. The average deformation value of the bolts installed on the right wall in the second support was approximately $50.9 \mathrm{~mm}$, as seen in Figure 18f. So, the average deformation value of the bolts installed on the left wall was $53.2 \mathrm{~mm}$, the average deformation value of the bolts installed on the right wall was $50.8 \mathrm{~mm}$, and the average deformation value of the bolts installed on the roof was $52.5 \mathrm{~mm}$. Compared with the deformation curve of Figure 15, the sum of deformation value of CRLD bolts installed on the left and right walls was basically the same as the 
shrinking value of the two walls-approximately $104 \mathrm{~mm}$. Additionally, the average deformation value of bolts installed on the roof was close to the subsidence value of roof-approximately $52 \mathrm{~mm}$.

These results indicate that the tensile deformation of the CRLD bolts is consistent with the deformation of the surrounding rock and the tensile deformation value is far less than the largest design deformation of the CRLD bolt. Therefore, the CRLD bolt can effectively control the deformation of the surrounding rock at the first support and the second support, and can still carry out an effective support function in deformation control, thereby effectively verifying the effectiveness of the CRLD bolt in the support process. So, the proposed coupling support countermeasure can effectively control the nonlinear large deformation of the surrounding rock and help to maintain the stability of the deep soft rock roadways.

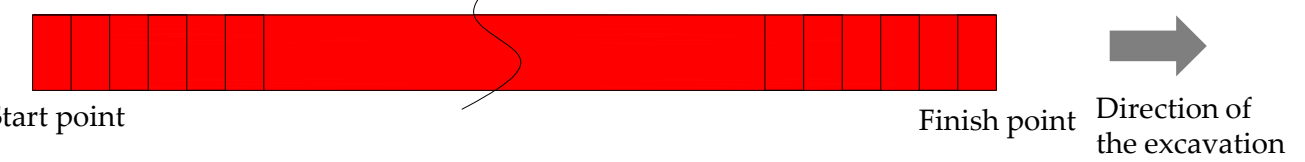

(a)

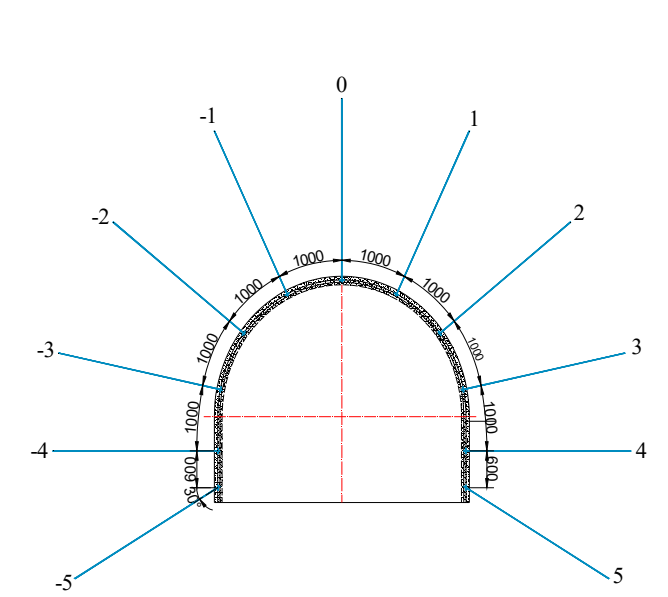

(b)

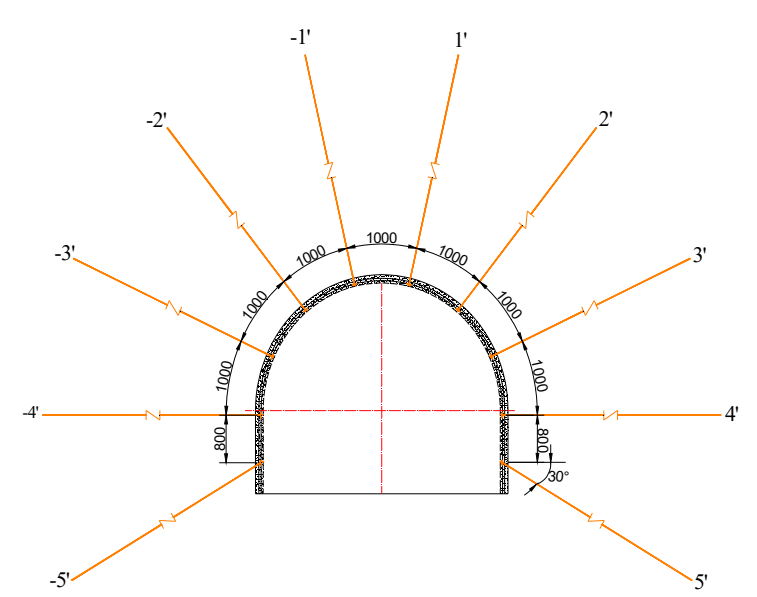

(c)

Figure 17. Serial numbers of CRLD bolts of the test period of the roadway: (a) Row numbers of CRLD bolts; (b) Serial number of each row of CRLD bolts in the first support; (c) Serial number of each row of CRLD bolts in the second support.

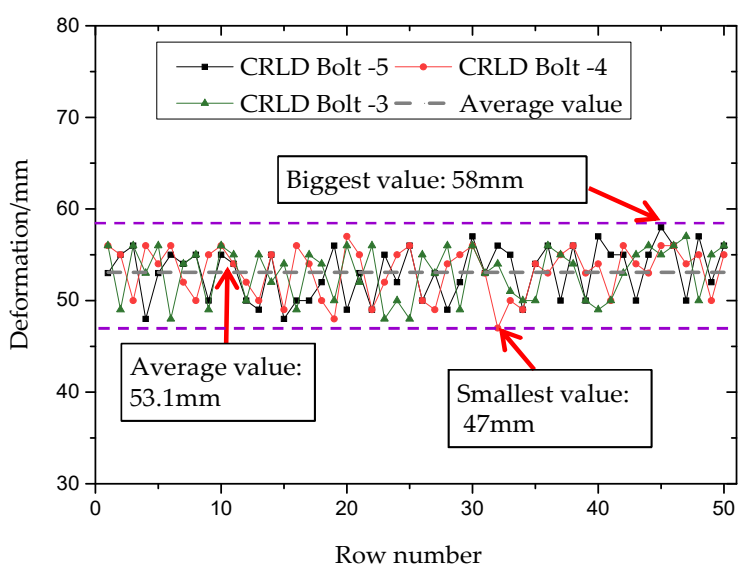

(a)

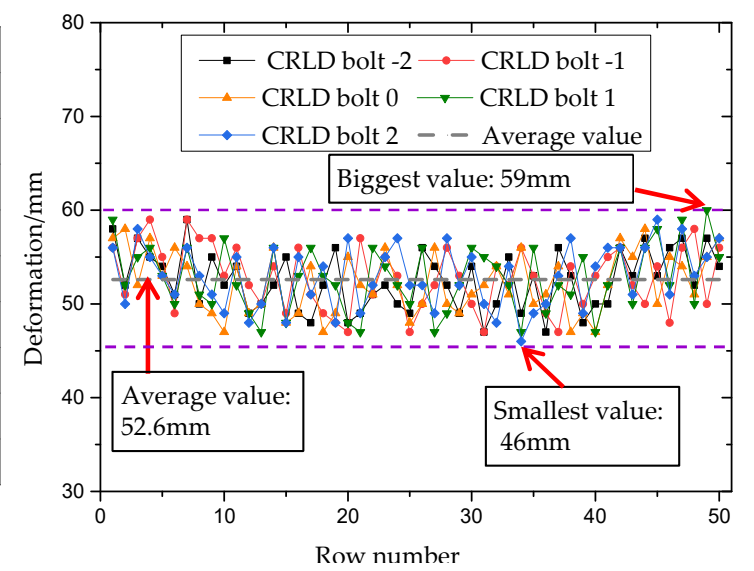

(b)

Figure 18. Cont. 


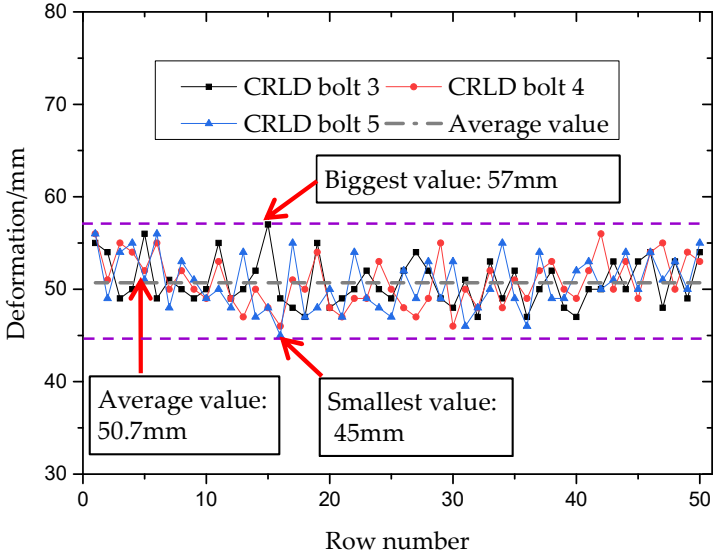

(c)

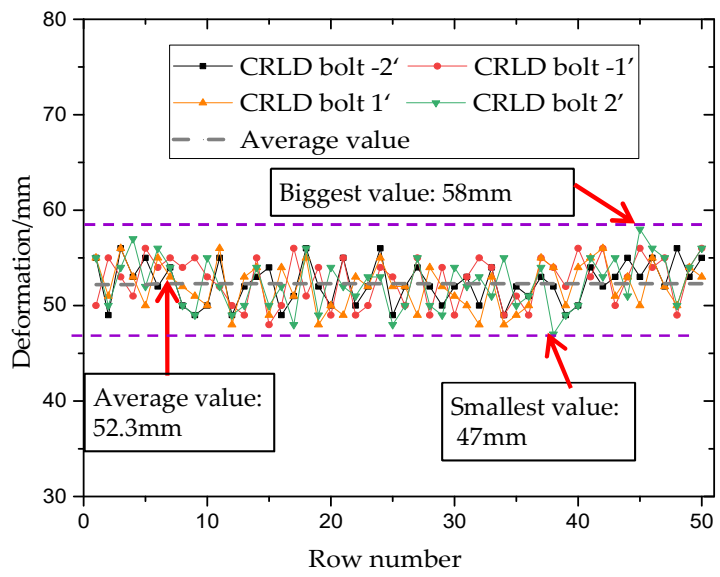

(e)

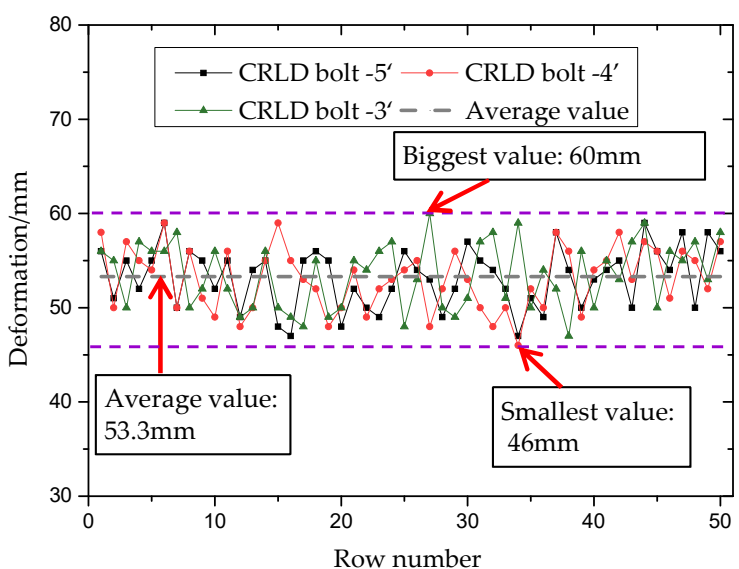

(d)

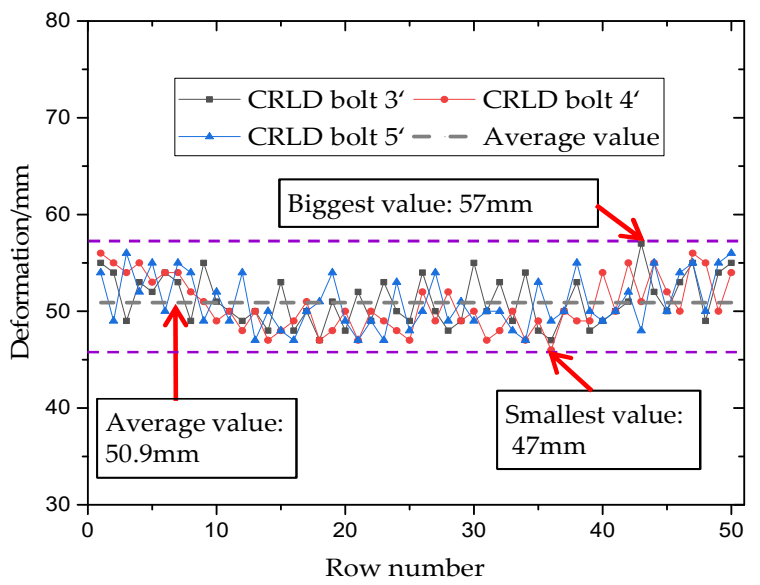

$(\mathbf{f})$

Figure 18. Deformation of CRLD bolts: (a) CRLD bolts installed in the left wall in the first support; (b) Deformation of CRLD bolts installed in the roof in the first support; (c) CRLD bolts installed in the right wall in the first support; (d) CRLD bolts installed in the left wall in the first support; (e) CRLD bolts installed in the roof in the first support; (f) CRLD bolts installed in the right wall in the first support.

\section{Conclusions}

1. Based on the X-ray diffraction and electron microscope scanning analyses of the deep soft rock samples, some characterristics of the rock samples can be concluded: (1) the rock samples contain a large amount of clay minerals (54.5\%) - among which, the kaolinite content is the largest $(44.5 \%)$, the illite/smectite mixture layer content (39.6\%) takes second place, and the illite content $(13.8 \%)$ is lower. These properties are in line with the characteristics of clay mineral composition in Mesozoic soft rocks. (2) The kaolinite and illite/smectite mixture layer are mostly disordered structures arranged in sheets and flocculations. (3) There is a large number of dissolution holes on the mineral surface-some of which are filled with argillaceous components and calcite. (4) The microfissures in the rocks are well developed, and the connectivity of some fissures is good, with some of these filled with calcite and other crystals.

2. Through field investigation, the nonlinear large deformation characteristics can be summarized as follows: (1) serious argillization and desertification of the soft rock; (2) asymmetrical floor heave deformation; (3) shear-slip deformation of the roof; (4) asymmetrical shrinkage of the side walls; (5) damage to support materials.

3. The surrounding rock has been ascertained to be the composite deformation mechanism, $\mathrm{I}_{\mathrm{AB}} \mathrm{II}_{\mathrm{ABD}} \mathrm{III}_{\mathrm{BC}}$, which is transformed to a simple one by targeted measures. According to the design principle of the deep roadway and coupling support concept, the coupling support 
design, which contains CRLD bolt, steel mesh, floor hollow grouting cable, and steel fiber concrete, has been proposed.

4. The CRLD bolts positively controls the development of roof and side wall deformation through the release of stress accumulated by the swelling soft rock. The floor hollow grouting cable positively controls the continued development of the floor heave by cutting off the slip line of the base angle. It is advantageous to form a unity for the roadway and support to ensure the coupling effect of the support design and stability of the roadway and indict the advantage of the coupling support concept. Therefore, the proposed coupling support countermeasure can effectively control the nonlinear large deformation of the surrounding rock and help to maintain the stability of the deep soft rock roadways. This can be used as a reference for the nonlinear large deformation mechanism and support technology of deep soft rock roadways under similar geological conditions.

Author Contributions: Conceptualization, X.S.; Data curation, D.W.; Investigation, H.L.; Project administration, H.Z.; Writing—original draft, D.W.; Writing—review and editing, Y.J. and X.S.

Funding: This research was financially supported by the National Natural Science Foundation of China (No. 51874311), the Applied Research Project for Postdoctoral Researchers of Qingdao (No. 2015205), the Open Project of State Key Laboratory of Mining Disaster Prevention and Control Co-founded by Shandong Province and the Ministry of Science and Technology (No. MDPC201609), the Open Project of State Key Laboratory for Geomechanics and Deep Underground Engineering in CUMTB (No. SKLGDUEK1727).

Conflicts of Interest: The authors declare no conflict of interest.

\section{References}

1. The British Petroleum Company (BP p.l.c.). BP Statistical Review of World Energy 2019; BP p.l.c.: London, UK, 2019.

2. Department of Energy Statistics of China National Bureau of Statistics. China Energy Statistical Yearbook 2018; China Statistics Press: Beijing, China, 2019.

3. Xie, H.P.; Gao, F.; Ju, Y. Research and development of rock mechanics in deep ground engineering. Chin. J. Rock Mech. Eng. 2015, 34, 2161-2178.

4. He, M.C.; Xie, H.P.; Peng, S.P.; Jiang, Y.D. Study on rock mechanics in deep mining engineering. Chin. J. Rock Mech. Eng. 2005, 24, 2803-2813.

5. Xie, H.P. Research framework and anticipated results of deep rock mechanics and mining theory. Adv. Eng. Sci. 2017, 49, 1-16.

6. Yuan, L. Strategic thinking of simultaneous exploitation of coal and gas in deep mining. J. China Coal Soc. 2016, 41, 1-6.

7. Kang, H.P. Support technologies for deep and complex roadways in underground coal mines: A review. Int. J. Coal Sci. Technol. 2014, 1, 261-277. [CrossRef]

8. He, M.C. Progress and challenges of soft rock engineering in depth. J. China Coal Soc. 2014, 39, $1409-1417$.

9. Gao, Y.B.; Liu, D.Q.; Zhang, X.Y.; He, M.C. Analysis and optimization of entry stability in underground longwall mining. Sustainability 2017, 9, 2079. [CrossRef]

10. Yang, X.J.; Wang, E.Y.; Wang, Y.J.; Gao, Y.B.; Wang, P. A study of the large deformation mechanism and control techniques for deep soft rock roadways. Sustainability 2018, 10, 1100. [CrossRef]

11. Yang, X.J.; Pang, J.W.; Lou, H.P.; Fan, L.P. Characteristics of in situ stress field at Qingshui coal mine. Int. J. Min. Sci. Technol. 2015, 25, 497-501. [CrossRef]

12. Jager, A.J. Two New Support Units for the Control of Rockburst Damage. Int. J. Rock Mech. Min. Sci. Geol. Abs. 1994, 31. [CrossRef]

13. Charette, F.; Plouffe, M. Roofex-Results of Laboratory Testing of a New Concept of Yieldable Tendon. In Proceedings of the 4th International Seminar on Deep and High Stress Mining, Perth, Australia, 7-11 November 2007; pp. 395-404.

14. Li, C.C. A new energy-absorbing bolt for rock support in high stress rock masses. Int. J. Rock Mech. Min. Sci. 2010, 47, 396-404. 
15. He, M.C.; Gong, W.L.; Wang, J.; Qi, P.; Tao, Z.G. Development of a novel energy-absorbing bolt with extraordinarily large elongation and constant resistance. Int. J. Rock Mech. Min. Sci. 2014, 67, $29-42$. [CrossRef]

16. Eugie, K.; Wang, Y.M. Review on rockburst theory and types of rock support in rockburst prone mines. Open J. Saf. Sci. Technol. 2005, 5, 104-121.

17. Sun, X.M.; Zhang, Y.; Wang, D.; Yang, J.; Xu, H.C.; He, M.C. Mechanical properties and supporting effect of CRLD bolts under static pull test conditions. Int. J. Min. Met. Mater. 2017, 24, 1-9. [CrossRef]

18. Sun, X.M.; Wang, D.; Wang, C.; Liu, X.; Zhang, B.; Liu, Z.Q. Tensile properties and application of constant resistance and large deformation bolts. Chin. J. Rock Mech. Eng. 2014, 33, 1765-1771.

19. Yang, X.J.; Pang, J.W.; Liu, D.M.; Liu, Y.; Tian, Y.H.; Ma, J.; Li, S.H. Deformation mechanism of roadways in deep soft rock at Hegang Xing'an coal Mine. Int. J. Min. Sci. Technol. 2013, 23, 307-312. [CrossRef]

20. He, M.C.; Gao, Y.B.; Yang, J.; Gong, W.L. An innovative approach for gob-side entry retaining in thick coal seam longwall mining. Energies 2017, 10, 1785. [CrossRef]

21. Sun, X.M.; Wang, D.; Feng, J.L.; Zhang, C.; Chen, Y.W. Deformation control of asymmetric floor heave in a deep rock roadway: A case study. Int. J. Min. Sci. Technol. 2014, 24, 799-804. [CrossRef]

22. Wang, H.W.; Xue, S.; Jiang, Y.D.; Deng, D.X.; Shi, S.Z.; Zhang, D.Q. Field investigation of a roof fall accident and large roadway deformation under geologically complex conditions in an underground coal mine. Rock Mech. Rock Eng. 2018, 51, 1863-1883. [CrossRef]

23. Yu, W.J.; Wang, W.J.; Chen, X.Y.; Du, S.H. Field investigations of high stress soft surrounding rocks and deformation control. J. Rock Mech. Geotech. Eng. 2015, 7, 421-433. [CrossRef]

24. Luan, H.J.; Jiang, Y.J.; Lin, H.L.; Wang, Y.H. A new thin seam backfill mining technology and its application. Energies 2017, 10, 2075. [CrossRef]

25. Luan, H.J.; Jiang, Y.J.; Lin, H.L.; Li, G.F. Development of a new gob-side entry-retaining approach and its application. Sustainability 2018, 10, 470. [CrossRef]

26. He, M.C.; Jing, H.H.; Sun, X.M. Soft Rock Engineering Mechanics; Science Press: Beijing, China, 2002.

27. He, M.C.; Sun, X.M. Support Design and Construction Guide of Soft Rock Roadway Engineering in Chinese Coal Mines; Science Press: Beijing, China, 2004.

28. He, M.C. Conception system and evaluation indexes for deep engineering. Chin. J. Rock Mech. Eng. 2005, 24, 2853-2858.

29. Zhang, N.; Liu, L.B.; Hou, D.W.; He, M.C.; Liu, Y.L. Geomechanical and water vapor absorption characteristics of clay-bearing soft rocks at great depth. Int. J. Min. Sci. Technol. 2014, 24, 811-818. [CrossRef]

30. Guo, H.Y.; Li, B.; Zhang, Y.M.; Wang, X.B.; Zhang, F. Hydrophilic characteristics of soft rock in deep mines. Int. J. Min. Sci. Technol. 2015, 25, 177-183. [CrossRef]

31. Guo, H.Y.; Zhao, J.; Liu, P.Y. Experimental studies and chemical analysis of water on weakening behaviors of deep soft rock. Chin. J. Rock Mech. Eng. 2018, 37, 3374-3381.

32. He, M.C.; Yang, X.J.; Sun, X.M. Study on Clay Mineral Characteristics for Soft Rock of Coal Mine in China; China Coal Industry Publishing House: Beijing, China, 2006.

33. He, M.C. Deformation mechanics mechanism and support measures of soft rock in coal mine. Chin. J. Hydrogeol. Eng. Geol. 1997, 2, 12-16.

34. Sun, X.M.; He, M.C.; Yang, X.J. Research on nonlinear mechanics design method of bolt-net-anchor coupling support for deep soft rock tunnel. Rock Soil Mech. 2006, 27, 1061-1065.

(C) 2019 by the authors. Licensee MDPI, Basel, Switzerland. This article is an open access article distributed under the terms and conditions of the Creative Commons Attribution (CC BY) license (http://creativecommons.org/licenses/by/4.0/). 